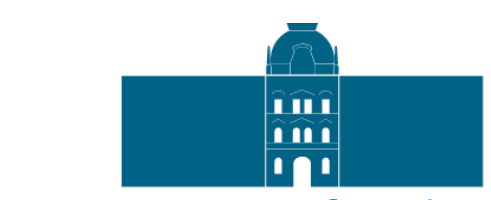

University of Maribor

Faculty of Tourism

\title{
HANDBOOK FOR WRITING AND EDITING TEXTS OF THE FACULTY OF TOURISM OF THE UNIVERSITY OF MARIBOR
}

Edited by:

Mladen Knežević, Ph. D.

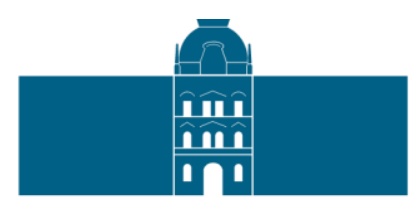

University of Maribor Press 



\section{HANDBOOK FOR WRITING AND EDITING TEXTS OF THE FACULTY OF TOURISM OF THE UNIVERSITY OF MARIBOR}

PROFESSIONAL MONOGRAPH

\section{Edited by:}

Mladen Knežević, Ph. D. 
Title: Handbook for writing and editing texts of the Faculty of tourism of the University of Maribor

Subtitle: Professional monograph

Editor: assoc. prof. Mladen Knežević, Ph.D. (University of Maribor, Faculty of tourism)

Authors: assist. prof. Mitja Gorenak, Ph.D. (University of Maribor, Faculty of tourism), assist. prof. Borut Vojinović, Ph.D. (University of Maribor, Faculty of tourism), assist. prof. Andreja Trdina, Ph.D. (University of Maribor, Faculty of tourism), lect. Boris Prevolšek, M.Sc. (University of Maribor, Faculty of tourism), assist. prof. Marko Koščak, Ph.D. (University of Maribor, Faculty of tourism), assist. Barbara Pavlakovič (University of Maribor, Faculty of tourism), assist. Maja Rosi (University of Maribor, Faculty of tourism), assist. Nejc Pozvek (University of Maribor, Faculty of tourism)

Language Review: Lekteja, Lektoriranje, Teja Bačar, s. p.

English translation: PREVAJANJE ZA VAS, Boštjan Grošelj, s. p.

Co- University of Maribor, Faculty of Tourism, Cesta prvih borcev 36, 8250 Brežice,

Publisher/Izdajateljica: Slovenia, tel. +386 820540 10, http://ft.um.si, ft@um.si

Publisher/Založnik: University of Maribor Press, Slomškov trg 15, 2000 Maribor, Slovenia, tel. +386 250 42 42, http://press.um.si, zalozba@um.si

Issue: First edition

Publication type: Electronic material

Available from: http://press.um.si/index.php/ump/catalog/book/292

Year of issue: 2017

\section{(C) University of Maribor Press}

All rights reserved. No part of this book may be reprinted or reproduced or utilized in any form or by any electronic, mechanical, or other means, now known or hereafter invented, including photocopying and recording, or in any information storage or retrieval system, without permission in writing from the publisher.

This handbook was discussed and approved by the Commission for Study Affairs at the Faculty of Tourism and the Senate of the Faculty of Tourism.

CIP - Kataložni zapis o publikaciji

Univerzitetna knjižnica Maribor

$001.89(035)(0.034 .2)$

HANDBOOK for writing and editing texts of the Faculty of tourism of the University of Maribor [Elektronski vir] : professional monograph / edited by Mladen Knežević ; [authors Mitja Gorenak ... [et al.] ; English translation Prevajanje za vas, Boštjan Grošelj s. p.]. - 1st ed. - El. priročnik. - Maribor : University of Maribor Press, 2017

Način dostopa (URL): http://press.um.si/index.php/ump/catalog/book/292. - Izv. stv. nasl.: Priročnik za pisanje in urejanje besedil Fakultete za turizem Univerze v Mariboru

ISBN 978-961-286-105-6 (pdf)

doi: 10.18690/978-961-286-105-6

1. Gorenak, Mitja 2. Knežević, Mladen, sociolog

COBISS.SI-ID $\underline{93336065}$

ISBN: $\quad 978-961-286-105-6$ (pdf)

978-961-286-106-3 (Softback)

DOI: https://doi.org/10.18690/978-961-286-105-6

Price: Free copy

Responsible person prof. Igor Tičar, Ph.D., rector of the University of Maribor of the publisher:

DOI https://doi.org/10.18690/978-961-286-105-6

(C) 2017 University of Maribor Press

Available from: http://press.um.si 


\title{
PRIROČNIK ZA PISANJE IN UREJANJE BESEDIL FAKULTETE ZA TURIZEM UNIVERZE V MARIBORU
}

\author{
dr. Mladen Knežević
}

\section{POVZETEK}

Učni proces na fakulteti ne zahteva samo udeležbe na predavanjih in dejavnega sodelovanja na vajah, temveč tudi intenzivno individualno delo študenta. To se mnogokrat predstavi v obliki seminarske naloge oziroma pisnega dela. Najbolj pomembno samostojno delo študenta pa je zagotovo zaključna - diplomska ali magistrska naloga. Da bi študentom Fakultete za turizem Univerze v Mariboru predstavili in olajšali pripravo pisnih del, smo na fakulteti pripravili priročnik za pisanje in urejanje besedil. Strokovna monografija zajema poglavja, ki študenta vodijo skozi celoten proces raziskovanja in pisanja dela. Od začetnega iskanja ideje, osnov znanstvenega pisanja in raziskovanja $v$ turizmu, do posameznih korakov raziskovalnega procesa in raziskovalnih metod. $V$ strokovno monografijo je vključeno tudi poglavje o osebnih odnosih, ki še posebej nagovarja odnos med študentom in mentorjem pri pisanju zaključnih del. Priročnik podaja tudi praktične nasvete o jezikovnem in tehničnem oblikovanju besedila ter navajanju literature in virov. Strokovna monografija tako združuje temeljne informacije, ki jih bodo pri svojem delu uporabljali študenti in predavatelji, saj bodo skupaj sledili enotnim smernicam pisanja besedil $v$ turizmu na Fakulteti za turizem.

KLJUČNE BESEDE: Pisanje besedil, urejanje besedil, raziskovanje, citiranje, tehnično oblikovanje besedil

KORESPONDENČNI NASLOV: Univerza v Mariboru, Fakulteta za turizem, Cesta prvih borcev 36, 8250 Brežice, Slovenija, e-pošta: ft@um.si.

DOI https://doi.org/10.18690/978-961-286-105-6

ISBN 978-961-286-105-6 (pdf)

(C) 2017 Univerzitetna založba Univerze v Mariboru

Dostopno na: http://press.um.si 


\title{
HANDBOOK FOR WRITING AND EDITING TEXTS OF THE FACULTY OF TOURISM OF THE UNIVERSITY OF MARIBOR
}

\author{
Mladen Knežević, Ph.D.
}

\section{ABSTRACT}

The learning process at the faculty requires not only attending lectures and active participation in the tutorials, but also intensive individual work of a student, which is often presented in the form of a seminar paper. However, the most important individual work of a student is definitely a final paper - a diploma or a master's thesis. In order to present and facilitate the preparation of written works for the students of the Faculty of Tourism of the University of Maribor, we have prepared this handbook for writing and editing texts at the faculty. The professional monograph covers the chapters that lead the student through the whole process of research and writing their paper. From the initial search of the research idea and the basics of scientific writing and research in tourism, to the individual steps of the research process and research methods. The professional monograph also includes a chapter on personal relationships, which in particular addresses the relationship between a student and a mentor in the process of preparing the paper or thesis. The handbook also provides practical advice on language and text designing, as well as instructions for citing references. The professional monograph, thus, combines basic information that both students of tourism and their lecturers will use in their study and work processes, as they will follow the uniform guidelines for writing texts in tourism at the Faculty of Tourism.

KEY WORDS: Writing texts, editing, research, citing, text designing

CORRESPONDENCE ADDRESS: University of Maribor, Faculty of Tourism, Cesta prvih borcev 36, 8250 Brežice, Slovenia, e-mail: ft@um.si.

DOI https://doi.org/10.18690/978-961-286-105-6

ISBN 978-961-286-105-6 (pdf)

(C) 2017 University of Maribor Press

Available from: http://press.um.si 


\section{TABLE OF CONTENTS}

CHAPTER 1: INTRODUCTION TO SCIENTIFIC THINKING AND WRITING........................... 1 -

CHAPTER 2: SCIENTIFIC RESEARCH IN THE FIELD OF TOURISM ........................................ 5 -

CHAPTER 3: STEPS OF THE RESEARCH PROCESS....................................................................- 9 -

CHAPTER 4: DEFINITION OF THE RESEARCH METHOD; BETWEEN THE QUALI- AND

QUANTITATIVE .................................................................................................................. 23 -

CHAPTER 5: PERSONAL RELATIONS IN SCIENTIFIC WRITING ………………………........ 35 -

CHAPTER 6: LANGUAGE AND THE STYLE OF WRITING ……….......................................... 43 -

CHAPTER 7: CITATION OF LITERATURE AND SOURCES........................................................ - 49 -

CHAPTER 8: FORMATTING OF THE TEXT................................................................................. - 65 - 



\section{EDITORIAL}

Student's written work in the university academic environment is not just a task in the learning process (which definitely is), but also a culture sui generis ${ }^{1}$, or to put it more precisely, a part of the culture. This claim that it is also a part of the culture does not only refer to the cultural forms of the individual writing his work; it also includes the expansion and deepening of the cultural approach of the academic institution where this work is being prepared. The teaching staff is therefore grateful to students for all their efforts during the course of their studies.

This monograph is not just a set of instructions for students regarding how to prepare a written work or just a reminder for the mentors regarding certain perhaps somewhat forgotten elements of the structure of the written work in academic promotion of their candidates. It is a joint contribution to the common culture. In my opinion, cultural tourism does not represent a special category because there are no clear distinctions between the cultural and other forms of tourism. This category does not exist because tourism is a culture on its own and not just a part of an already existing, more or less local or localised culture. It is a culture on its own. It is from the perspective of tourism as a culture that we provide the following material: not only as a set of instructions on how to prepare a written work, but also as a call to the mentors and students to participate in the expansion of cultural horizons of the tourism industry in the Slovenian society. Every written work you make is a new contribution to the culture. It is also a test of whether and how well the faculty exercises its mission for the development and refinement of the Slovenian cultural area.

Since culture primarily relates to the development, the present monograph does not play any role in the establishment of criteria or rules. It is a companion on the path of development and promotion of students as well as the teaching staff. Development never stops at a certain reference point but is a continuous journey into the future.

The preparation of this monograph included many associates. Not just authors signed under individual articles, but also their mentors and authors whose works were eagerly read and included in the very foundations of their academic promotion. This is precisely the characteristic of the culture - continuous development and reliance on predecessors. And much more: reliance on predecessors and their desire and ability to take certain ideas into infinity. This is exactly what the teaching staff expects from students: to take into the future this culture the knowledge, desires, opportunities and abilities of our generation of academic inhabitants of this small part of the world called Slovenia.

The publication of this monograph was contributed to by Mitja Gorenak Ph.D., Borut Vojinovič Ph.D., Marko Koščak Ph.D., Andreja Trdina Ph.D., Boris Prevolšek, Maja Rosi, Barbara Pavlakovič and Nejc Pozvek. I would honestly like to thank them all for their investment in this joint material. I especially have to mention Mitja Gorenak Ph.D. whose work brought to light the idea of this monograph, who constantly looked after its creation and brought it to its final appearance provided to our students and pedagogical colleagues teaching at the Faculty of Tourism of the University of Maribor.

Editor, Mladen Knežević, Ph. D.

${ }^{1}$ Latin: referring to something special, i.e. an original culture, one of its kind. 



\section{CHAPTER 1}

\section{INTRODUCTION TO SCIENTIFIC THINKING AND WRITING \\ Author: Mitja Gorenak, Ph.D.}

DOI: https://doi.org/10.18690/978-961-286-076-9.1

The same as in case of other scientific disciplines, research in the field of tourism is constantly evolving. Unfortunately, we have to establish that tourism is still not recognized as an independent scientific discipline after all. The multidisciplinary nature of research in the field of tourism and also very diverse interests in both science and practice are, to a large extent, the reason why tourism has not yet been established as an independent scientific discipline, because (too) many people relatively simply consider it as a sub-category of some other existing scientific discipline. It is exactly in this context that we have to emphasize that research in the field of tourism has to follow the established principles of scientific thinking and writing because they can help us reach the level of quality of scientific research in the field of tourism and consequently establish tourism as an independent scientific discipline.

Scientific text is very complex; in order for an individual to write it, this individual must first devote a considerable amount of time to scientific thinking. We need to clarify that scientific thinking is actually a matter of the approach to thinking which is independent from the research area; the field of tourism as well as any other scientific discipline requires thorough scientific thinking. We first have to determine the purpose of the research itself because this is the guideline that follows of throughout the entire research process. We will talk more about the purpose of research in the following sections, but the very purpose of the research basically divides scientific research into two large groups; basic scientific research on one hand, and applicative scientific research on the other.

The basic research once represented the major part of research and was extremely important for the development of human civilization, since the basic research accelerates the development of theories. The aim of basic research is perfectly clear - new discoveries (Easterby-Smith, Thorpe and Lowe, 2007). Here, we have to make it perfectly clear that discoveries are infrequent and can be completely unpredictable or, to a certain extent, expected according to previous research. It is possible to talk about a discovery when the research results in a change of mindset, a somewhat different explanation that changes the previously existing thinking about a certain topic. Nevertheless, discoveries represent only one of the numerous possible conclusions of the basic research. The conclusion that every researcher finds the sweetest. When the basic scientific research results in a new treatment of the same problem, perhaps a new technological approach, we can talk about an invention (ibid.). This is the other form of the conclusion of the basic scientific research. Basic research can also lead to a third possible result which is less popular - reflection. When the researcher concludes the basic research with the definition of the application of the existing theory or technique in a certain completely different context of application in the organizational and social field, we can talk about reflection on the application of the theory or technique (ibid.). 
The applicative scientific research is focused on solving real problems (Eastervy-Smith, Thorpe and Lowe, 2007). It focuses on the identification of specific problems of organization or identification of certain practical problems from the everyday environment (ibid.). The characteristic feature of applicative research is that it is based on knowledge acquired through basis research and that it is focused on achieving a certain practical or applicable objective. Applicative research therefore develops ideas of the basic research into an applicable form. We can say that it is development oriented and strongly integrated in the development of the economy (Lorber, 2003).

The relation between the basic and the applicable research is constantly changing; if basic research once represented the major part of research, we can now see a more balanced situation. While the research institutions and countries, to a large extent, continue to support basic research, the applicative research receives greater support from the economy which is expected and understandable given the nature of research.

Values are the element that should not be overlooked in scientific thinking and writing. Over time, the so called neutral ideal (Lacey, 2005) prevailed in science. It emphasised and favoured the objectivity in scientific research. In this context, the established claims could only be true or false; it all depends on the evidence presented by the scientist or researcher and nothing depends on the values of the scientist or researcher (Weber in Kirn, 1988). This means that science only states the observed facts without any values involved and that all further decisions related to the research facts are not in the domain of the scientist or researcher, but simply left to those that deal with the consequences of these findings.

Such approach to science, which excludes scientist's or researcher's value identification is somewhat differently set and understood in today's research world. Lacey (2005) says that we it is possible to see objectivity coming to the fore which is without a doubt the most important in scientific work. Here, a question arises whether the scientist or researcher can be objective if his decisions include his own values.

Douglas (2000) has no doubts regarding the aforementioned question and points out that values play their role even before the very start of a certain research. She divides values into values with direct and indirect impacts. The scientist or researcher is therefore individually responsible to define the problem of the research and to select the methodology (Douglas, 2000). Here, we should point out a thought by Login (1990) who says that especially the applicative research, often ordered by companies that define the subject of research (and also fund the research), on one side, and the scientists or researchers on the other side, often depend on such financial support in the modern world. Because research in the field of tourism often depends on the financing by the economy it is not immune to the problem of the gap between the values. Even more: Cases may occur where the use of values of the client financing the project can lead to scientific falsifications with irreversible damage for the research.

Douglas (2000) emphasizes that the values of the researcher and the client do not always match. Therefore, the values of the researcher play a very important role when accepting (or refusing) the project. Values, their ethical component actually, play a decisive role in the selection of the research methodology. As pointed out by Douglas (ibid.), the ethical acceptability of the selected methodology directly impacts on all further work of the scientist 
or researcher because ethical values play a legitimate role in the evaluation of the selected methodology especially where the research includes people or other living beings.

In her further work, Douglas (2009) emphasized that the direct role of values is not always acceptable, since, even though they have a direct influence on the selection of the methodology, they should not have any influence on the determination of the methodology because it is connected with the definition of the problem that was set at the beginning and is independent from the values. We can say that values should not determine scientific methods. We can also add another thought by Login (1990) and Douglas (2009) who say that science, if lead exclusively by values, would reflect too many prejudice, desires and needs and would become incompetent to present a real and dependable understanding of the phenomena and consequently the surrounding world.

In the context of the debate regarding the inclusion of values in scientific research it is also appropriate to discuss the topic which lately often falls in this area - the problem of plagiarism. In accordance with the definition from Slovar slovenskega knjižnega jezika (SSKJ), plagiarism is text that is transcribed, copied from elsewhere and published, presented as one's own. The very definition clearly states what plagiarism is, but it is also important to understand the problem of plagiarism in the context of scientific research work. Every scientist or researcher tends to provide the world with his own new findings, to share them with the world and to contribute to further development of science and indirectly the world. It is therefore completely intolerable and unacceptable to claim a certain content as one's own if it is a part of the content by some other author. The task of the scientist or researcher is to upgrade the existing findings on the basis of appropriately identified sources that have to be clearly marked. In order to avoid plagiarism, numerous institutions across the entire world (including the University of Maribor) established systems of checking the authenticity of individual's texts. Nevertheless, the fact remains that we (still) do not have a perfect verification system; it is still the responsibility of each individual scientist or researcher to act in accordance with the moral and ethical principles.

\section{Literature:}

Douglas, H. (2000). Inductive risk and values in science. Philosophy of science, 674), 559579.

Douglas, H. (2009). Science, policy, and the value-free ideal. Pittsburgh: University of Pittsburgh Press.

Easterby-Smith, M., Thorpe, R. and Lowe, A. (2007). Raziskovanje v managementu. Koper: Univerza na Primorskem, Fakulteta za management Koper.

Lacey, H. (2005). Is science value free?: Values and scientific understanding. London; New York: Routledge.

Longino, H. E. (1990). Science as social knowledge: Values and objectivity in scientific inquiry. Princeton: Princeton University Press. 
Lorber, L. (2003). Prenos znanja in tehnologij kot spodbujevalec regionalnega razvoja. Podravina: časopis za multidisciplinarna istraživanja, 2(3), 76-89.

Slovar slovenskega knjižnega jezika (2016). Plagiat. Available from: http://bos.zrcsazu.si/cgi/a03.exe?name=sskj_testa\&expression=ge\%3Dplagiat*\&hs=1，November 12 , 2016.

Weber, M. (1988). Smisel vrednotne nevtralnosti socioloških in ekonomskih znanosti. In A. Kirn (Ed.), Znanost v družbeno vrednotnem svetu (58-103). Ljubljana: Delavska enotnost. 


\title{
CHAPTER 2
}

\section{SCIENTIFIC RESEARCH IN THE FIELD OF TOURISM}

\author{
Author: Borut Vojinović, Ph.D.
}

DOI: https://doi.org/10.18690/978-961-286-076-9.2

Tourism as a field of study in the Republic of Slovenia is, in accordance with the classification of education, marked with the code Klasius P-812. It belongs to a wider area which is marked with the code 8 - Services, or its subcategory 81 - Personal Services (Statistični urad Republike Slovenije, n.d., p. 38). Such definition is based on the classification by the Organisation for Economic Cooperation and Development (hereinafter referred to as OECD) in the so-called Frascati Manual (OECD, 2015). The Klasius classification actually defines fields of study, whilst research areas are covered by the classification presented by the OECD (2015; it was established in a small town of Frascati in the central Italy by a wide range of researchers) and is today known as the Frascati Manual.

For many decades, the scientific community was exposed to numerous debates about integration of tourism in research; on one hand it is possible to find researchers who understand tourism as a completely independent discipline (Leiper, 1981, Tribe, 1997, Leiper, 2000) and call it »tourismology « (Jovičić, 1988), and the researchers who reject any form of division of the research area (Echtner and Jamal, 1997) on the other hand. Regardless of the quite different perspectives we can determine that tourismology is lately becoming increasingly recognised as an independent scientific research area which is characterised by a distinctive connection with numerous other areas (Pansiri, 2005; Cardia, 2015). From this perspective we can talk about interdisciplinarity which is widely opening in almost all scientific areas. Today, it is almost impossible to find a scientific discipline that would be completely »genuine« no matter whether we are talking about natural or social sciences. In the context of the above mentioned we will discuss tourismology as an independent scientific area connected primarily to personal services.

Scientific research in the field of tourism is therefore distinctively interdisciplinary. Most commonly, it is possible to find research connected with diverse business functions (e.g.: organization of work, marketing of products, human resource management, destination management, economic impacts, finances, etc.). From a broader perspective, the field of tourism also includes somewhat more sociological perspective on tourismological research (e.g.: interpersonal relations, power and influence, political aspects, etc.) as well as a somewhat more psychological perspective on tourismological research (e.g.: individual's perception, influence of the media, consumer behaviour, etc.). Due to the intertwining of the aforementioned areas, research in the field of tourism often falls in the area of interdisciplinary research. In this context other research areas are also included (e.g.: ethnography, geography, event management, sports and free time, etc.), but we have to point out the importance of the basic research in the field of tourism. Other research areas can only supplement research in the field of tourism and can never replace it. 
As already mentioned above, we can expect that the major part of research in the field of tourism will be performed in the context of the researcher focusing on an individual element(s) of tourism which is why we can talk about the so-called tourismological research. Such research includes the analysis of a very diverse range of various factors; for example: organizational forms in tourism (organization of work), sales approaches (product marketing), employee satisfaction (human resource management), sustainable development (destination management), tourism demand and supply (economic impacts), return on investments in tourism (finances), etc. Within the framework of the sociological perspective on tourismological research we can talk about research; for example: communication with co-workers/clients (interrelations), attitude of the local environment towards tourism (power and influence), international agreements/wars/migration flow (political aspects), etc. Within the framework of the psychological perspective on tourismological research we can talk about research in the fields of the perceived value of the product (individual's perception), reputation of a certain company/organization (influence of the media), changes and human habits (consumer behaviour), etc. These are only some of the examples. We certainly should not limit tourismological research only to these examples, since any of these disciplines offers an even broader scope of examples. Regardless of the type of research we select depending on the content, the following step (decision on the research method) should in any event be in accordance with this decision. Regardless of whether the research will be performed in the field of tourism or in another field, we can distinguish between two different approaches to research, descriptive and analytical (Zelenika, 2000). Metaresearches also include a third important approach, the so-called evaluation approach. This is an approach that is regarded as very demanding and requires very thorough methodological knowledge.

The descriptive approach includes description of operation, facts, structure or course of a certain tourism phenomenon and/or process. The framework of the descriptive approach includes three important forms. This includes the classifying procedure where the selected tourism categories are classified according to the same or similar characteristics. The comparative method is a procedure of comparison of comparable tourism categories (relations, conditions, phenomena, etc.). Such comparison of tourism categories helps us determine the similarities and differences between these categories. The comparative method helps the researcher to achieve generalization and come to new conclusions. The next method within the framework of descriptive approach is the historical method. With the help of the selected historical documentation we can determine what was happening and what happened in the past. As the last method in the set of the descriptive research we have to indicate the compilation method where the conclusions and/or descriptions of the analyst are based on findings and/or discoveries by others (with the help of citation we include findings and discoveries by other authors who have researched this field before us).

In case of the analytical approach, the research is somewhat different. Here, the facts, the structure or the course of a certain tourism impact and/or process are no longer described, but are studied in an analytical manner. Within the framework of the analytical approach, tourismological research includes two different research techniques: induction (inductive approach) and deduction (deductive approach).

The deductive approach is a way of logical conclusion and offers thorough understanding of phenomena and their background (Žižmond, 1998). In the first phase we determine the 
interconnections and interdependencies between various tourism phenomena and processes under study in our research on the basis of the elements of the deductive tourismological analysis, tourismological laws and theoretical knowledge. In case of such conclusions we can presume that if, for example, the Ministry of Finance decides to increase the excise duty on alcoholic beverages sold on the market (including the alcoholic beverages sold within the framework of tourism services) this measure will increase the price of alcoholic beverages. We can deductively conclude that the increase of excise duties will consequently result in the increase of retail prices of alcoholic beverages which will probably decrease the demand for such beverages.

Inductive tourismological research: With the collection and analysis of the collected data we are checking and determining the accuracy of findings that were analysed above with the help of the deductive tourismological approach to research (i.e. the assumption that higher excise duties bring higher price of the product and consequently decreased demand). In this part of research, which is usually second, we use diverse statistical methods to deductively test, supplement, correct or change the claims. The inductive tourismological research is therefore primarily empirical and statistical and provides numerical results. If we use the previous example, where we came to a deductive conclusion that higher excise duties bring decreased demand, we collect the data about the prices of alcoholic beverages and the demand for such beverages (special attention should be paid to the statistical characteristic or the significance of the selected statistical sample in the selected methodology where it is reasonable to ask the mentor for advice) in a selected time period (EPF, 2013a, 2013b and 2013c). On the basis of the selected data we can calculate what actually happened with the increase of excise duties, and use the acquired result (with the inductive approach to the collected data) to conclude that, for example, an $8 \%$ increase of excise duties on alcoholic beverages results in a $0.9 \%$ decrease in the demand for alcoholic beverages in tourism services. In this manner, we confirmed our above mentioned deductive claim that the increase of excise duties on alcoholic beverages will consequently result in the increase of retail prices of alcoholic beverages which will probably decrease the demand for such beverages.

We have defined two phases of tourismological research, i.e. inductive and deductive. The third phase of most of the tourismological research also includes the phase of deductive tourismological research where we interpret the data collected in the previous phase. This can lead to the establishment of new theories, claims, and hypotheses arising from previous ones.

Of course, not all approaches are necessary for all levels of research in the field of tourism; much depends on the researcher's level of complexity when dealing with a certain problem. This will be further discussed in the following chapters.

\section{Literature:}

Cardia, G. (2015). The Four Arrows of Knowledge Applied to Tourism. Revista de Análisis Turístico, (18), 1-10.

Echtner, C. M. and Jamal, T. B. (1997). The disciplinary dilemma of tourism studies. Annals of tourism research, 24(4), 868-883. 
EPF. (2013a). Postopki in pravilniki za prijavo teme in zagovor sklepnega dela visokošoolskega strokovnega programa "Poslovna ekonomija". Available from: http://www.epf.um.si/studenti/Vsebina/postopek_diplomiranja_VS.aspx, November 24, 2016.

EPF. (2013b). Postopki in pravilniki za prijavo teme in zagovor sklepnega dela univerzitetnega študijskega programa "Ekonomske in poslovne vede". Available from: http://www.epf.um.si/studenti/Vsebina/postopek_diplomiranja_UN.aspx, November 24, 2016.

EPF. (2013c). Postopki in pravilniki za prijavo teme in zagovor sklepnega dela študijskega programa 2. stopnje "Ekonomske in poslovne vede". Available from: http://www.epf.um.si/studenti/Vsebina/postopek_diplomiranja_BM.aspx, November 24, 2016.

Jovičić, Ž. (1988). Osnovi turizmologije. Beograd: Naučna knjiga.

Leiper, N. (1981). Towards a cohesive curriculum tourism: The case for a distinct discipline. Annals of tourism Research, 8(1), 69-84.

Leiper, N. (2000). An emerging discipline. Annals of Tourism Research, 273), 805-809.

OECD (2015). Guidelines for Collecting and Reporting Data on Research and Experimental Development. Available from: http://www.oecd-ilibrary.org/science-andtechnology/frascati-manual-2015_9789264239012-en;jsessionid=41juba9l5n1jo.xoecd-live-02, November 27, 2016.

Pansiri, J. (2005). Pragmatism: A methodological approach to researching strategic alliances in tourism. Tourism and Hospitality Planning \& Development, 2(3), 191-206.

Statistični urad Republike Slovenije (n.d.). Struktura in opisi kategorij klasius-P. Available from: http://www.stat.si/doc/klasif/Klasius_P.pdf, November 24, 2016.

Tribe, J. (1997). The indiscipline of tourism. Annals of tourism research, 24(3), 638-657.

Zelenika, R. (2000). Metodologija i tehnologija izrade znanstvenog i stručnog djela. Rijeka: Ekonomski fakultet u Rijeci.

Žižmond, E. (1998). Kako nastane pisno delo. Maribor: Ekonomsko-poslovna fakulteta. 


\title{
CHAPTER 3
}

\section{STEPS OF THE RESEARCH PROCESS}

\author{
Author: Andreja Trdina, Ph.D.
}

DOI: https://doi.org/10.18690/978-961-286-076-9.3

The basic characteristic of the scientific activity is systematics, organization and control of the cognitive effort. We are talking about efforts that would like to contribute to the understanding of phenomena they are dealing with. We can describe scientific research as a »rationalexperiential activity where the researcher acquires new knowledge in an organized, systematic, controlled and planned manner « (Toš and Hafner Fink, 1998, p. IV). Research is therefore an organized and systematic process where an important role is played by planning. This is where scientific research significantly differs from everyday curiosity or solving of problems from everyday situations. Distinction ${ }^{2}$ between them is not necessarily in the subject of research itself, but in the method. Methodology deals with general rules or procedures of scientific research (ibid., p. 13). In everyday research process and in all kinds of scientific research it is compulsory to follow methodological principles because they guarantee objectivity of the entire research procedure and its results.

In all kinds of research, applicative as well as fundamental, the research idea represents the fundamental preliminary step in the research process. The research idea can arise from the interest of the researcher himself or from the need of the client ordering the research. The research process basically includes the following steps: conceptualisation, operationalization and implementation of the research (Knežević and Bizjak, 2009, p. 16):

1) Conceptualisation relates to the selection and definition of the research problem, definition of the purpose and objectives of the research, and formulation of hypotheses and research questions.

2) Operationalization includes definition of the research plan, variables and methods for the collection of data.

3) Implementation of the research includes the actual collection of data (primary and secondary) and the analysis and interpretation of data.

As an organized and systematic process, research is a most complex process. How and where to start the research often poses a dilemma especially for novice researchers. In the following sections we will identify individual steps of the research process, hoping that they will help students as novice researchers in the preparation of their final papers.

\subsection{SELECTION OF THE TOPIC/RESEARCH AREA (REVIEW OF THE LITERATURE)}

Because the field of tourism represents an interdisciplinary area addressed by various scientific disciplines it is necessary to clearly place research work into a specific disciplinary area within

2 Distinction, from Latin (distinctio) - distinction, distinguishing, difference. 
the framework of which it will be implemented. It is possible to study a certain subject of research from very diverse disciplinary starting points (e.g. tourism development of a certain destination can be studied through various perspectives: question of carrying capacity of the tourism destination, networking of stakeholders in the local community, attitude of the local community towards tourists, environmental, social and economic impacts on the host community, organization of work of the providers of tourism services or the economic indicators of tourism industry, etc.). Research starts with the selection of the framework topic where we place our interest into a specific research area (e.g. economy or marketing, event management, destination management, sociology of tourism, psychology in tourism, cultural heritage and tourism, etc.) thereby determining the conceptual apparatus that will be used.

When we determine the broader research area we have to define the narrow problem to be researched within the framework of this area (destination image, stereotypes in tourism, etc.). We cannot study the entire area, but we have to clearly limit our focus. Narrowing of the focus represents a big challenge. We have to find the perfect equilibrium in the relationship between the general and the specific. Very general topics are inappropriate for empirical research. We have to focus on the analysis of a certain concrete research problem and place it in the framework of the existing findings that serve us as a theoretical framework. At the same time we should point out that, at least at this level of research, the majority of students' final papers actually include a reverse process where the author (student) first decides for a certain very concrete problem or subject of the research which he then places into a broader area with the purpose of establishing a theoretically and methodologically acceptable framework.

Review of the literature, where we familiarize ourselves with the key theories and concepts in our research area and with the existing studies and findings of various authors, represents a most important step in the research process and in the attempt of narrowing down our focus. This gives us a better insight into the actual trends when studying the topic and the estimate which areas have already been more or less studied. Accurate and reasoned definition of our problem therefore requires a thorough study of the literature. When selecting the literature, the student should orient himself according to the following criteria:

- He should primarily look for scientific work (monographs, collections of scientific papers, magazine articles) and secondary for professional literature.

- The literature should include older, classical or canonical works that represent the milestones in the development of a certain area and are more often cited than the modern works which include new findings in the area.

- Already when selecting and studying the literature, the student should take into consideration that citation of secondary literature should only be the exception. If certain literature is unavailable to the student, this literature should only be referenced by a secondary author. Otherwise it is expected from the student to find the original literature.

- It is expected that the student is familiarized with articles by relevant authors in the field, domestic as well as foreign. 


\subsection{DEFINITION OF THE RESEARCH PROBLEM (AND ITS RELEVANCE)}

Definition of the problem or the subject of research is, as already mentioned before, the first step of the scientific research procedure. »The problem accepted as the subject of a certain research work is most commonly the one that causes problems when solving everyday work tasks as well as problems in the understanding or use of a certain theory. Solving of this problem leads to the progress in a certain work process, or progress in the theoretical understanding in a certain area « (Knežević and Bizjak, 2009, p. 17).

It is essential that our research problem is well reasoned and that we explain its relevance. We have to ask ourselves why the problem or the subject of research is important and why it should be studied. In other words, we have to reason why it is socially and scientifically relevant to deal with the selected problem. The answer to this question can be given on the basis of the review of the literature and the already performed studies in the area under consideration, as well as with the description of the socio-historical context that includes the subject of research. Research problems are most often promoted by the theoretical and methodological predicaments or socio-historical conditions (context including the problem and from which we can explain the need for research). The selected research problem can therefore be based on the discrepancy between the theory and practice, research gap (filling in blind spots and voids not yet reflected upon) or disagreement between the authors. In case of applicative projects, their relevance is additionally reinforced with practical interests of the economy or other subjects. The relevance and the importance of the research problem are shown through its placement into an actual theoretical framework or through its practical and social relevance.

If the first phase included focusing on finding and reviewing large volumes of literature, this point should include a thorough and critical study of literature and theories concretely relating to our research problem or the subject of research. It is of key importance that we critically judge what is important and what is not. In such manner we selectively and deliberately establish a theoretical or conceptual framework of our research work.

Due to the importance of this phase of the research process, some consider the narrowing of the focus on the selection of the specific research problem as the most creative part of the research process itself (Vujević in Knežević and Bizjak, 2009, p. 19). The importance of the unambiguous and clear definition of the research problem is neatly illustrated by a though by Einstein that the formulation of the problem is often more important than the solution itself. The problem actually guides the researcher through the research process from the beginning to the end, which is why it must be clearly indicated and its relevance precisely defined and reasoned. Even the most careful further corrections or in-depth procedures in later phases of research, whose design was already wrong, cannot eliminate the initial mistakes. »The more explicit the researcher's initial ideas (or 'analytical framework), the more obviously the researcher is guided to what needs to be studied and what can be ignored in accordance with the infinite volume of information provided by each individual situation or case« said Ragin (2007, p. 19). 


\subsection{PURPOSE}

Each research work has its purpose that answers the question of what will the results of research serve for. According to the purpose, we basically distinguish between the basic scientific research and the applicative research (for more information see Chapter 1 ).

The basic research is an experimental or theoretical work with the help of which we would mainly like to acquire new knowledge about the phenomena without predicting any special use of such knowledge. Basic research is therefore predominantly dealing with the construction, review and improvement of the basic knowledge and theories in a certain scientific area. The results of such research are usually not intended for sale, but are published in scientific literature or forwarded to other interested experts. However, the applicative research is directly and primarily focused on a certain practical objective or purpose. With the help of the applicative research we would like to determine how to use the results of the basic research or to define new methods or ways to achieve the practical objectives that were determined in advance (Miklič Milek, 2012, pp. 113-114).

Research work or its results can therefore be intended to spread scientific findings or to improve theoretical knowledge (by supporting, supplementing or even rejecting a certain part of previous theoretical knowledge), or, on the other hand, to solve a certain completely practical problem in the field of tourism activity (e.g. management of tourism organization). The purpose of research is therefore defined outside the project. It arises from the motivational factors of those that are most interested in the findings of a certain research. A clear and explicit definition of the purpose of research is important because it represents a step towards the definition of the objectives of research (as cited in Knežević and Bizjak, 2009, p. 19).

\subsection{OBJECTIVES}

The objectives of the research have to be defined based on the decision regarding the purpose of the research. These objectives are related to the nature of the subject of research and arise from the purpose of research (set by the researcher or the client ordering the research work). We distinguish between three possible objectives of the research process: 1) description, 2) explanation and 3) evaluation which are in the following sections cited from Knežević and Bizjak (2009, pp. 20-22):

\section{Description}

The research can have a completely descriptive objective as a way of researching certain phenomena, social conditions and relations or behaviour of certain subjects. The descriptive research allows to describe the area which is the subject of the research. In the field of tourism, such research is most often performed because:

a) the area is relatively new, particularly in case of scientific research work,

b) the area is very dynamic and includes plenty of changes, and

c) because the results of the descriptive research can be relatively quickly applied in the industry.

Example: The subject of description in the research process can be various aspects of the tourism activity or tourist behaviour, e.g. to describe how much money tourists on average 
spend at a certain destination, how they arrive to the destination, which are the elements of the destination that attracted the tourists, etc.

\section{Explanation}

The explanatory objective reveals a certain causality in the interrelation between factors that are active in a certain area. The function of such objective is explanatory. It explains the operation of variables in a certain concrete environment and their interrelations. The interconditionality (causality) between the variables is a general precondition for understanding of such processes, especially for the prediction of further trends in this area which can represent a most important step in the tourism industry, whether we are talking only about theoretical work, or a certain analysis that will contribute to the practical decisions taken by managers.

Example: The objective of the research is, for example, to explain why tourists find a certain destination more and more interesting; explain the reasons for a negative attitude of the local population towards tourists in a certain destination; explain the influence of satisfaction at work on the motivation of workers in the field of tourism; explain the impact of the media on the formation of destination image, etc.

\section{Evaluation}

Evaluation is an objective which the scientists or practicians set when they want to evaluate the performance of a certain programme or policy in the field of tourism activity. Evaluation as the objective of a certain research is a very complex and multi-layer procedure. It includes several phases that can actually represent an independent research project:

a) Evaluation of needs (definition and evaluation of needs as the motivation for a certain process),

b) Analysis of the very process of the programme (including evaluation of the evaluability of the process - whether the programme is conceptualised and operationalized in the manner that allows reliable and valid evaluation),

c) Analysis of the results (outputs) or the performance of the programme (e.g. costbenefit analysis, i.e. analysis from the perspective of the cost rationality of the programme), and

d) Phase of observation and monitoring of the programme.

Example: The objective of research can be evaluation of the performance of a certain programme/project in the field of tourism activity. In such research we have to set and clearly define certain criteria which will be used to evaluate the execution or the results of the activity of a certain programme/project in a certain time/geographical/work area.

\subsection{ESTABLISHMENT OF RESEARCH QUESTIONS, HYPOTHESES OR THESES}

Establishment of research questions, hypotheses or theses is extremely important for the preparation of the research. The entire research depends on the clarity of the formulation and precise determination of the research question or hypotheses or theses because hypotheses/theses/research questions represent the concretisation of the research problem 
that directs the researcher towards certain actions. We have to take care that hypotheses and research questions are clearly and unambiguously indicated. No matter whether we are researching with the help of research questions or hypotheses we have to take care that they are probable and reasoned.

Quantitative research includes establishment of hypotheses, whilst qualitative research includes establishment of research questions; in case of theoretic work that does not include empirical research we talk about theses (for more information see the following sections).

The research question helps us precisely define the cognitive objectives of research work. It is unnecessary to establish the research question in an interrogatory form. It can be established in an affirmative form (we can ask ourselves: What are the motives to visit destination $X$, or say: We will research the motives to visit destination $X$ ). Research question can therefore be a question or a claim that is not directly subjected to the process of scientific demonstration or verification, but a question that primarily limits the research area and consequently directs our research. The research question has to be clearly formulated and without complex sentences. In case of a complex problem this is solved by forming sub-questions. General research questions are usually made more concrete with a few sub-questions when we are more familiarized with the subject of research (as cited in Hafner Fink and Škerlep, n.d.).

If the formation of research questions requires care and precision, the establishment of hypotheses requires even more care because it demands empirical verification. Hypotheses are »scientific assumptions for which the researcher believes that can help him explain a certain phenomenon or set of phenomena « (Toš and Hafner Fink, 1998, p. 58). Hypothesis is established in such manner that it formulates specific characteristics or interrelations between the phenomena and in such manner that these characteristics or interrelations can be verified. Hypotheses have to include only claims that can be empirically checked. A good hypothesis is a specific claim that leads to new findings about the phenomena we intend to study. However, it nevertheless has to be logically placed in the theoretical framework of the research.

We distinguish between descriptive and relational hypotheses:

- Descriptive hypotheses presume a certain characteristic, state or the course of the phenomena. We are talking about hypotheses reflecting the claim about the existence of the phenomenon, frequency of the phenomenon, intensity of the phenomenon or the duration or formation of a certain phenomenon (Toš and Hafner Fink, 1998, pp. $59,69-70$ ) (e.g. the level of motivation amongst the employees of the hotel chain $X$ is high./Most of the respondents have negative image of destination X.).

- Relational hypotheses are richer in content because they reflect relations or interrelations between the phenomena. They are directed only to the connection or correlation between the phenomena, or even to a cause and effect interrelations between them (Toš and Hafner Fink, 1998, p. 59, 71) (e.g. the higher the number of tourists at destination $X$, the higher the level of dissatisfaction of the residents of the destination with tourism.).

Establishment of hypotheses enables the control of the research process and direction of our work towards the problem that is determined as the subject of research. This is why 
hypotheses have to include the following characteristics (as cited in Knežević and Bizjak, 2009, p. 19):

1. They have to be established in accordance with the problem.

2. They have to be established clearly, unambiguously and precisely (they should not be formed in a way that allows several explanations; they have to reflect the nature of a certain phenomenon, its relation with other phenomena).

3. The manner of the establishment has to allow their falsification (their formation has to be exclusive which allows the verification of their content; hypotheses »there will be raining here tomorrow or not« cannot be empirically disproved).

4. They have to be formed in a manner that allows experiential (empirical) verification (hypothesis claiming that the reduction of the number of tourists is caused by an unusual phenomenon cannot be empirically verified).

5. Hypotheses have to be probable and reasoned from the very beginning (research based on improbable and unreasoned hypotheses is a waste of time).

6. Hypotheses have to have the highest explanatory - predictive power possible, i.e. they have to be as productive as possible (the more productive they are, the more it is possible to use them to explain a broader area of the phenomenon which is the subject of research).

7. Hypotheses have to comply with the already established and verified hypotheses that relate to the subject of research (in cases where this is not possible due to the insufficient breakdown of the research area, we have to approach this ideal as much as possible).

8. Hypotheses have to be as simple as possible (when choosing between two hypotheses we should select the simpler one. This selection also has to take into account the reality because the simpler hypothesis occasionally does not cover the meaning area that is broad enough).

According to the degree of generality we can define hypotheses as general, special and individual (Toš and Hafner Fink, 1998, p. 67):

- general hypotheses are established from the broadest perspective possible and cover the phenomenon in its entirety;

- special hypotheses relate to narrower parts of reality - according to the claims included in the general hypothesis;

- individual hypotheses only include the narrowest segments or parts of the included phenomenon and often relate to particular situations and events.

Generally, the first part of the research process includes the establishment of the general hypothesis that includes the subject of research in its entirety. The subject of research can be further covered with several special hypotheses, from which every hypothesis covers its own perspective of the subject of research or part of the research problem to be explained. Figure 1 shows the ratio of special hypotheses that jointly cover the entire circle that represents the subject of research. Only the system of hypotheses that allows perfect coverage of the subject 
of research can lead to accurate results. In other words, the more complex the subject of research, the more the complex system of hypotheses requires for its explanation (as cited in Knežević and Bizjak, 2009, p. 30).

Figure 1: Ratio of hypotheses and the subject of research

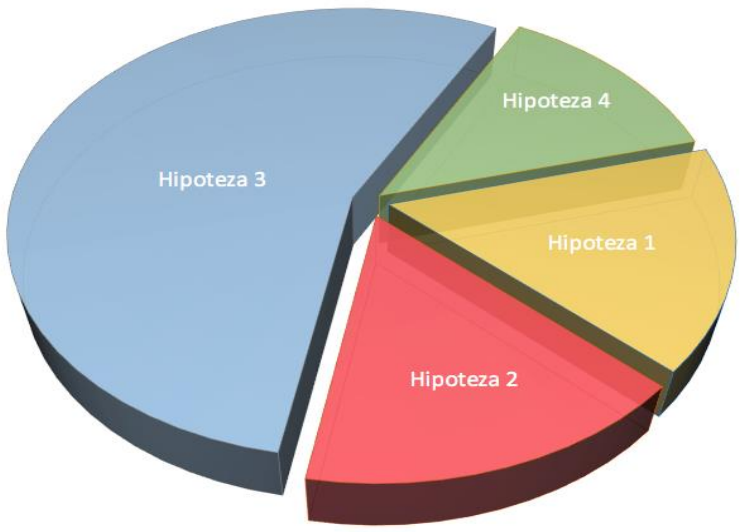

Source: Adapted from Knežević and Bizjak, 2009, p. 30

If the hypothesis represents the characteristic of the empirical research, we generally talk about a thesis in the framework of theoretical work. Thesis is a theoretical claim which is, at the level of a theory, »verified « in a manner that includes verification of the consistency of the thesis in the context of a concrete theory, theoretical model or at the level of the relation between different theories. Formulation of the thesis requires similar requirements as formulation of the hypothesis: clarity, simplicity, logic, verifiability (this time at the level of the theory), non-triviality, etc. (as cited in Hafner Fink and Škerlep, n.d.).

\section{Examples of good and bad hypotheses and research questions}

Hypothesis 1: Poor working conditions are the most frequent reason for employee dissatisfaction.

Hypothesis 1 is a great example of well-established hypothesis. Provided that we perform the measurements appropriately, this hypothesis can be empirically verified. It clearly defines interactions and is simultaneously completely simple.

\section{Hypothesis 2: Older employees have longer length of service than younger employees.}

At first sight, hypothesis 2 can be seen as perfectly good, but verification of such hypothesis proves something completely logical and self-evident. While it is verifiable, it lacks explanatory value because its verification does not prove anything new. This is an example known as a »trivial hypothesis in methodology which in the context of the discussed topic represents a self-evident general finding or just definition of the concept placed in the centre of the research.

\section{Research question 1: What knowledge does a good manager require?}

Research question 1 is widely formed, but with the presumption that we are studying a certain case (e.g. organization) we can use this research question to come to conclusions which knowledge will the manager require to perform his job well. 
Research question 2: Can we raise the reputation of the organization?

At first sight, the research question 2 looks quite appropriate. However, with this type of questions we would throughout the entire research only try to answer the first word of this question, i.e. »can«. The word »can « presumes a binary answer; it can only be answered with »yes « or »no " which is not enough for serious research. The mere replacement of the question word (e.g. with »how «) changes this question and transforms it into a completely appropriate and well-formed question.

\subsection{RESEARCH PLAN: SELECTION OF THE METHOD AND COLLECTION OF DATA}

The answer to the question of which method to use depends on the research problem and what interests us regarding this problem, the depth and scope of the problem, and which information is required for its solution (Trunk Širca, Jošt and Skrbinjek, 2012, p. 39). An important part of the methodological plan is therefore the decision regarding which research paradigm will the research belong to - whether we will have a qualitative approach (e.g. indepth interviews, observation with participation, discourse analysis, etc.) or a quantitative approach (e.g. survey research, content analysis, etc.). The quantitative approach focuses on the connections between the small number of characteristics in case of a large number of cases/units, whilst the qualitative approach deals with the connections between a large number of characteristics within the framework of a relatively small number of cases/units (Ragin, 2007, p. 12). Quantitative research is directed by the tendency of generalization, whilst the qualitative research is directed by in-depth understanding of the subject of research. For a more thorough distinction between the paradigm of qualitative approach and the paradigm of quantitative approach see chapter 4 . The differences between quantitative and qualitative methodology are presented in Table 1.

Table 1: Quantitative and qualitative methodology

\begin{tabular}{|l|l|l||}
\hline & Quantitative & Qualitative \\
\hline Role of the researcher & External perspective & Participation in the environment \\
\hline Course of the research & Deduction & Induction \\
\hline Collection of data & Standardisation & Adaptation to the environment \\
\hline Number of observed units & Large & Small \\
\hline $\begin{array}{l}\text { Number of observed } \\
\text { characteristics }\end{array}$ & Small & Large \\
\hline
\end{tabular}

Source: As cited in Toš and Hafner Fink (in Trunk Śrca, Jošt and Skrbinjek, 2012, p. 36)

Selection of the qualitative or quantitative methodology depends primarily on our problem. The decision for the appropriate method/technique of data collection is taken in accordance with the definition of the research problem.

a) The quantitative research should be selected when we detect a large number of »objects« or analysis units in the research and when the findings relate to the population of these analysis units. In this case we usually talk about a classical model of testing hypotheses about the connections between the variables, i.e. connections between the characteristics of the 
observed units. Survey research is a typical quantitative research. It includes a sufficiently large number of respondents which allows us to perform the statistical analysis of the collected data. Content analysis is also a quantitative research. Here, the subject of research represents a large number of »objects « (texts or messages, such as newspaper articles or advertising messages in a certain time period, etc.). In all cases we talk about approaches that allow somewhat more general findings (as cited in Hafner Fink and Škerlep, n.d.).

b) We can talk about a qualitative research when we are observing a small number of objects referred to by the findings of the research. Qualitative research includes interviews (structured, semi-structured, biographic), focus groups or guided group conversations, and also observation with participation (it requires the researcher to participate in the research area and is usually a combination of several qualitative methods: ethnographic method, in-depth interview). In case of text analysis we are faced with a semiotic (character analysis) or discursive analysis (discourse analysis). Amongst the qualitative researches we could also include historical-comparative studies where the researcher deals concretely with the analysis of a certain historical process or event usually on the basis of primary (documents and participants' testimonies) and secondary sources (studies and discussions by other authors) (as cited in Hafner Fink and Škerlep, n.d.).

c) We should not ignore the option of combining these methods, i.e. combination of the qualitative and quantitative approach. The combined application of qualitative and quantitative methods is becoming a more and more frequently used research plan in the applicative as well as basic scientific area (e.g. see Lobe, 2006, about the triangulation and various types of complementarity of the qualitative and quantitative methods). In accordance with the nature of the research problem it is very often reasonable to appropriately combine the qualitative and quantitative approach even though they are basically completely different research paradigms (on one hand positivist research and interpretive research on the other; for more information see Table 1). Study case, also called the intensive study of a single case, that enables in-depth understanding of a certain phenomenon/unit can therefore combine different methods of data collection (Johansson, 2003). Within the framework of the study case of a certain tourist company we can therefore combine the survey amongst the employees of the studied company, semi-structured interviews with the members of the management board, statistical data about the company, analysis of documentation, and observation with participation in meetings in the company. In the combination of methods, qualitative and quantitative methods can be equal. The research can also be primarily quantitative, whilst the qualitative methods play a complementary role, and vice versa. It is quite often possible to detect two-phase research plans where the qualitative and the quantitative research follow each other in any sequence. The qualitative research is usually performed as the preparation or explanation of the results of the quantitative research (qualitative method (interviews) can serve as the explorative method in the preparation of the quantitative measuring instrument (survey questionnaire) or for explanation of the quantitative results after the performed quantitative research).

In the research plan we should also define whether we will collect data ourselves or whether we will use already collected data. We have to clearly indicate whether the research is an independent (primarily) empirical research where the researcher collects data himself with the help of various methods, or a secondary data analysis that includes processing of the available 
data that was already collected in various forms for other purposes (bases of statistical data, administrative sources, publications, articles, documents). If we decide for the primary (own) research we have to prepare a clear plan for the acquisition (collection) of data: definition of the method (observation, survey, semi-structured interview, content analysis, etc.), population and (if necessary) the sampling method, data collection time frame, etc. Decision for the primary collection of data is usually based on the knowledge and review of secondary studies, i.e. already performed studies. When considering the type of research it is always desirable to have a previous insight into secondary sources. Due to the higher reliability of data, drawing upon secondary data can sometimes be more reasonable than primary collection of a narrow segment of data. Because of the generally more quality sampling, secondary data also enable more in-depth explanations and generalization of the results than primary research that rarely meets such criteria. We would like to point out that the analysis of secondary data certainly is not less important than the collection and analysis of primary data. It often guarantees higher level of reliability and validity of the findings (in case of the proper quality of data, of course). This applies especially for the performance of the survey on a general population because a methodologically appropriate performance of the general sociological survey research (formation of the questionnaire, sample, data collection) is very demanding and time consuming for an individual, if not even impossible due to the financial and time constraints. It often occurs that the same research process reasonably combines both approaches: when using the existing statistical data we can perform independent semi-structured interviews. Examples of primary and secondary data are presented in Table 2.

Table 2: Data collection methods

\begin{tabular}{||l|l||}
\hline \multicolumn{1}{|c|}{ PRIMARY DATA } & \multicolumn{1}{|c||}{ SECONDARY DATA } \\
\hline $\begin{array}{l}\text { Data we acquire ourselves with the help of } \\
\text { various methods (survey questionnaire, } \\
\text { interview, observation with participation, } \\
\text { focus group, experiment, etc.). }\end{array}$ & $\begin{array}{l}\text { Already collected and available data (articles, } \\
\text { books, bases of statistical data, statistical } \\
\text { publications, official reports, legal acts, } \\
\text { administrative sources, documents, etc.). }\end{array}$ \\
\hline
\end{tabular}

\subsection{ANALYSIS AND INTERPRETATION OF DATA}

Data should be transparently arranged, analysed and interpreted, and the results presented in the light of the objectives of the research in accordance with the purpose of the research. We have to give meaning to the acquired data in accordance with the determined research problem - what can it tell us and what conclusions can we draw from it. We should not only present the data in a descriptive manner. The results should not be presented dully (shares/frequency of answers) but always interpreted in the light of our research problem. At this point we should also present any potential unexpected results and reflect on what they mean in relation to the solution of the research problem. During the analysis and interpretation of data we can help ourselves with various available data processing software tools (e.g. Microsoft Office Excel, SPSS, R-Commander, ATLAS.ti). 


\subsection{DISCUSSION AND FINDINGS}

In the framework of the research we should connect the objectives of the research with the results acquired in the course of the research procedure. In other words, findings should evaluate the results of the analysis according to the established hypotheses/research questions. Through the discussion we should combine the analysed and interpreted data in reasonable content sets and switch from the specific back to the general. Our findings are reincorporated into the theoretic framework by connecting and comparing them with the already known findings and previous research evidence.

In the conclusion, we should summarize the key findings of the research and specifically expose the potential research limitations - we should try to critically evaluate the research work and the results. The researcher should, at the same time, reflect on the contribution of the results to the theory and the opening of new innovative ways in the research of this problem - outline additional perspectives opened by the research and present the potential new research ways in this problem area.

Finally, we should add that the indicated phases in the research practice do not always take place completely successively ${ }^{3}$. According to the nature of the research problem we can often detect intertwining of these phases: the researcher usually studies the literature of a certain scientific field in a continuous manner until the completion of the research; it is also possible that he analyses certain data even before concluding with the collection of some other data, whilst he can simultaneously further define and complete it in the course of interpretation.

\section{Literature:}

Hafner Fink, M. and Škerlep, A. (n.d.). Napotki za prijavo magistrskega dela FDV. Available from: http://www.fdv.uni-lj.si/docs/o-fdv/napotki-za-prijavo-teme-mag-dela.docx, December 10, 2016.

Johansson, R. (2003). Case Study Methodology. International Conference "Methodologies in Housing Research", Stockholm, 22-24 September 2003. Available from: http://psyking.net/HTMLobj-3839/Case_Study_Methodology_Rolf_Johansson_ver_2.pdf, December 4, 2016.

Knežević, M. and Bizjak, B. (2009). Merjenja in nekateri merski instrumenti v turističnih raziskavah. Portorož: Turistica.

Lobe, B. (2006). Združevanje kvalitativnih in kvantitativnih metod - stara praksa $v$ novi preobleki? Družboslovne razprave, XXII(53), 55-73.

Miklič Milek, D. (2012). Družbeno odgovorno ravnanje in raziskovalna odličnost. 24. forum odličnosti in mojstrstva, Otočec 2012.

${ }^{3}$ Successively - in a serial or successive manner; one following another. 
Ragin, C. C. (2007). Družbos/ovno raziskovanje: Enotnost in raznolikost metode. Ljubljana: Fakulteta za družbene vede.

Toš, N. and Hafner Fink, M. (1998). Metode družboslovnega raziskovanja. Ljubljana: Fakulteta za družbene vede.

Trunk Širca, N., Jošt, V. and Skrbinjek, V. (2012). Pisna dela v visokem šolstvu in osnove raziskovanja. Celje: Mednarodna fakulteta za družbene in poslovne študije. 
$-22-$ 


\title{
CHAPTER 4
}

\section{DEFINITION OF THE RESEARCH METHOD; BETWEEN THE QUALI- AND QUANTITATIVE}

\author{
Author: Boris Prevolšek, M.Sc.
}

DOI: https://doi.org/10.18690/978-961-286-076-9.4

The purpose of the research, whether qualitative or quantitative, is to discover new findings that contribute to the existing knowledge and encourage researchers to undertake further research. For the purpose of the acquisition of new knowledge, the researcher may resort to qualitative or quantitative research as two very different techniques for the collection and processing of data.

In the following sections we will present both research methods, however, we will present the qualitative research method more precisely because its in-depth understanding of phenomena and their background is becoming increasingly popular in the field of research. While only quantitative research prevailed in the past, qualitative research is gaining increasing popularity because it tries try to capture the essence from all of the possible perspectives also during the process of triangulation.

Qualitative research, the term derives from the Latin word »qualitas« (quality, value, distinction, ability, etc.), is a research approach that uses experiential word of mouth and pictorial material in the collection and analysis of data. The emphasis is put on the description of the studied situations and on the understanding of the context where these situations occur (Vogrinc, 2008). It highlights the research of individual's subjective experiences. Qualitative research takes place in natural conditions and maintains the complexity of everyday situations and allows the researcher to acquire more realistic findings (Sagadin, 2001). Qualitative research methods are designed to help the researcher understand the participants, and especially what they say and do, with the consideration of the social and cultural environment (Myers, 2009). The researcher and the researchee are inseparably connected with a constant interaction between them where the emphasis is on inductive generalization - from individual to general.

Quantitative research derives from the Latin word »quantitas« (how much, quantity, volume). Its characteristic is finding the cause-effect connections between the researched phenomena (Sagadin, 2001). Quantitative research is characterized by statistical procedures, reduction of information with numerical data, positivist philosophy, result orientation, and emphasis on reliability (Mužić, 2004). Positivist philosophy is characterised by the view of the world in accordance with modern science, rejection of the religion, metaphysics and prejudice, and emphasis on the description and explanation of empirical facts (Vogrinc, 2008, pp. 9-10). 


\subsection{DEFINITION OF QUALITATIVE RESEARCH}

The course of the qualitative research can be defined as a set of short, consequent research cycles with the phases of the establishment of the hypothesis, collection and analysis of the material, definition of the problem and formulation of the new problem, repeated collection of the material, analysis, etc., following one another. Such research can be defined as sequential research based on the plan of research actions sequentially following one another in a short period of time, followed by the analysis of the collected empirical material (Mesec, 1997). The course of qualitative analysis can also be defined as a non-linear or spiral or cyclic where the researcher is not following the established channels and phases of the research, but, during the course of the research, keeps returning to the beginning of the research and also investigates the side aspects of the research with the purpose to repeat a certain part of the research and acquire new data (Neuman, 2003). At the beginning of the research, a certain image forms about the phenomenon that is completed in the course of research, thus allowing gradual expansion of the researcher's knowledge of the problem. Mesec (1997) explains this with the concept of the hermeneutic circle which can be explained with the fact that, when the research begins, we always have a certain image about the subject of research, regardless of its simplicity and vagueness. This starting understanding of the problem or subject is called pre-comprehension. Mužič (2004) explains that the non-linear course of the qualitative research is based on three stages, i.e. reproduction of data, arrangement of data and formulation of the conclusion. It is not necessary that these phases follow one another. They exchange and complete each another. Questions asked by the researchers in qualitative research (Myers, 2009): What is happening? Why is this happening? How did it come to this? When did it happen?

For the performance of qualitative research it is important that the researcher takes into consideration the characteristics of this research, i.e. the appropriateness of the use of an individual research method, data collection and analysis technique, as well as ethical principles. Within the framework of his research, the researcher has to clearly define his research problem and accurately and clearly define the research objectives. Based on the review of the literature, the researcher has to estimate whether there are any research gaps that may reasonably be researched. His research model has to draw on certain philosophical assumptions and also decide which research and data collection and analysis methods he will use.

The selection of the research method should include the estimate whether the method is appropriate for the established research question, whether the method will bring the desired results, what are the conditions and limitations of the use of this method, which methods are also appropriate, what knowledge is required for the proper use of the method, is it possible to simultaneously use various methods, and whether these methods are compatible.

The selection of the research method is followed by the decision regarding the data collection method where the qualitative research most frequently includes interviews, field work (observation) and review of the literature. Data collection methods can be used separately or in coordination with each other. Selection of the data collection method depends on the research topic, selected research methods and on the availability of data. Availability of data has a significant impact on the result of the research, since answers to the asked questions can only be reached on the basis of the sufficient amount of the collected data. Collection of 
data is followed by data analysis which includes various approaches, such as hermeneutic, semiotic, content analysis, etc. Despite the mentioned sequence of steps, the research process includes constant interaction; the researcher keeps returning to the initial steps in order to perfect his established research problem or to establish a more proper one.

\subsubsection{QUALITATIVE RESEARCH METHODS}

Research methods can be defined as demand strategies that help us understand and explain the researched phenomenon on the basis of the collected empirical data (Myers, 2009). Qualitative research methods serve as a research means that enables an insight into people's opinions and the circumstances in which they find themselves, thus providing information, such as their positions, emotions, opinions (Easterby-Smith, Thorpe and Lowe, 2005). All data resulting from research work is primary data, whilst secondary data includes data resulting from the already performed research. Qualitative research provides primary data which can represent the basis for further research. In this manner, we can directly acquire data with the help of the appropriate methods, and simultaneously guarantee validity, objectivity and reliability of the acquired data (Radonjič and Iršič, 2006). Amongst the qualitative research methods we will present action research and the study case which are the most frequently used as methodological approaches in qualitative research especially in the field of tourism. There is a wide range of other qualitative research techniques which include ethnography and grounded theory, for example.

The course of action research can be understood as a two-stage process. Baskerville and Myers (2004) say that the action research process is based on two phases. The first phase (so-called diagnostic phase) includes research of a certain phenomenon on the basis of mutual cooperation of the researcher and the researchee. In this phase, theories are reviewed in connection with the research phenomena. The next phase (so-called therapeutic phase) presents the possible changes and investigates their potential impacts.

The phrase »case study« has several meanings, of which the most simplified is that it represents a description of an individual case or situation based on which general conclusions of the researched phenomena can be drawn. Study case can refer to a social process, organization or any collective social group (Myers, 2009). Study case can be used in any phase of research. It can be used at the beginning of the very research when we have to disclose certain facts, factors or answer certain questions that arise in similar circumstances. Study case can also be used after the phase when all literature related to the research topic was collected and when this literature has to be reviewed and certain theories verified, explained or compared between each other. A key issue when using the study case is not when to use it, but what to study with it. Study cases can be positivist, explanatory or critical.

\subsubsection{QUALITATIVE METHODS AND DATA COLLECTION TECHNIQUES}

Qualitative techniques are interpretive techniques which the researcher uses to try to describe, decode, translate or in another way discover the meaning of certain, more or less, natural phenomena in the social world (Van Maanen, 1983). 
Selection of the method and data collection techniques depends on the selected research method, topic of research and the available data. When selecting the method it is important that the researcher is familiar with it. Namely: only well-knowledge of techniques can guarantee their proper use. Research methods and techniques allow us to collect primary data; such data was not previously published, but acquired directly from people or organizations. Unlike primary data, secondary data come from previously published books, newspapers, articles, etc. The very collection of primary data can lead to a rich and credible qualitative research if the researcher masters data collection techniques. There are several different data collection methods and techniques of which we will present the interview, observation and field work in more details. Data collection techniques also include the use of documents.

Interviews are most frequently used for study cases, whilst field work is used in case of ethnography. Nevertheless, the decision about the selection of data collection methods and techniques belongs to the researcher who takes it on the basis of previous knowledge.

Interviews are most definitely the most important data collection technique in the field of business studies and are used in positivist, interpretive and critical research. By listening, encouraging and directing the conversation with the interviewees, interviews enable us to collect rich data from people in different roles and situations (Myers, 2009, p. 121). Basically, we distinguish between structured, semi-structures and non-structured interviews.

Field work is often called observation with participation and/or field work and represents a way of collecting data about a certain phenomenon with the help of a direct human contact and observation of people in their natural environment. Huges (2005) defines field work as observation of people on the spot, in the environment they are situated in, and observation of the roles they play in a manner where the researcher becomes a part of their environment and appropriately records their behaviour by not causing any damage to the observed people. Wolcott (2005, p. 44) adds that field work is a type of data collection with direct cooperation of the researcher in social activities of an individual or a group. Direct personal participation of the researcher guarantees a certain level of understanding people.

Field work substantially differs from interviews because it allows better understanding of the phenomenon. While interviews require specifically determined time and space for its performance, field work can be performed anywhere and at all times. For the performance of the interview, the researcher only allocates a certain amount of time which is much shorter than in case of field work. Within the framework of field work the researcher participates in the researched group or organization for a longer period of time. Interviews are also more official and understood as the researcher's appearance before the interviewee, whilst field work takes place in a natural human environment where the researcher acquires information through non-formal conversations. It is in this connection that data, collected within the framework of interviews, is much more official or expected and not actual.

\subsubsection{ANALYSIS OF QUALITATIVE DATA}

Titling of the research topic or problem and the selection of the appropriate research methods and data collection techniques is followed by the analysis and interpretation of qualitative data. The major part of the analysis and interpretation of data is performed at the end of the 
research when the researcher tries to identify the most important information from a large volume of data. The researcher tries to arrange his data into an appropriate form that allows him to focus on the important aspects of his research. Data is therefore transformed into important conclusions that allow better understanding of the research area and contribute new knowledge to the already existing theories or knowledge (Myers, 2009). In the analysis of data, the researcher can use and properly coordinate various approaches that will be presented in the following sections.

Coding of data is most certainly the simplest way of data analysis. It includes the use of various codes to describe or summarize a certain sentence, paragraph or even large volumes of text. Miles and Huberman (1994) define codes as markings that we use to give a certain meaning to the collected data during the research. Analysis therefore begins with the formation of codes to be used for the arrangement of a large volume of data into categories that reduce this volume, and to enable better organization of this data and faster data analysis. According to Ryan and Bernard (2000), coding should follow six steps, i.e. sampling, identification of topics, formation of the list of codes, connection of codes with the text, and formation and verification of models. The framework of sampling includes identification of the text under analysis, exposure of key topics and preparation of the list of possible codes and their definitions. Certain codes are attributed with the text applicable to them. This is followed by the establishment of a model for checking how the topics, concepts, beliefs and behaviours are interconnected. The established model is then verified with the help of empirical data.

Notes are often used as an accessory in data analysis. They represent researcher's personal notes about what is happening during the course of the research or about the way how the researcher undertook the research. Such notes include researcher's thinking and, at the same time, his feelings and actions during the course of the research. Esterberg (2002) recognizes two types of notes - procedural and analytical. Procedural notes are focused on the course of the research and record how the researcher undertook the research and how he performed it. Such notes provide a rich insight into the very course of the research. Analytical notes focus on the research topic, i.e. collected data, and on the potential meaning of such data. These notes represent the first step in the establishment of final findings.

Analytical induction is a type of data analysis where we develop explanations about a certain phenomenon on the basis of a single or several cases. Ryan and Bernard (2002) explain that we should first define the phenomenon to be explained and the purpose of this explanation. This should be followed by verification of the explanation of a certain phenomenon with a large number of cases. During the course of verification, our explanation is supplemented with new knowledge provided by individual cases. This procedure continues until we develop a certain general explanation of the phenomenon that applies to all studied cases.

Analysis of qualitative data can also take place on the basis of a set of events that can be arranged in a chronological order. According to certain common characteristics, these events can be arranged in categories; this might be events that occurred in the same time period, or events with a different aspect of their interconnection. Events can be described in a form of a story, or summarized in a form of tables or time graphs (Miles and Huberman, 1994).

The critical incident represents an analysis of qualitative data whose core of research includes people's opinions about certain events or incidents (Miles and Huberman, 1994). Such 
analysis is a somewhat shortened form of the chain of events, because this approach allows systematic collection of important data related to certain events, analyses certain samples and enables the reader to identify key conclusions. Many different incidents are often studied together in order to identify any common characteristics. Although the critical incident techniques arise from the positivist approach they can also be used in the framework of the interpretive approach (Kain, 2004).

Content analysis is focused on the identification of the meaning of written or visual sources, such as newspapers or advertisements, by breaking down their content into categories (Payne and Payne, 2004). McNabb (2002) emphasises that the essential advantage of such data analysis is that it provides the researcher with a structured method based on which he can analyse the content of the text in a simple, clear and reproducible manner. The main weakness of such data analysis is that it often takes certain information out of the context which often causes the loss of the meaning of the entire text or makes it difficult to summarize such meaning. This is exactly why content analysis is only appropriate when the meaning of a certain text is strongly or clearly emphasised (McNabb, 2002). Content analysis is appropriate for searching repeated words and the way these words change through time therefore it is often used for the analysis of historical trends or interview texts.

Conversation analysis addresses language as a human activity. Unlike written sources, oral sources are unofficial, non-structured and often grammatically incorrect. The topic of conversation often changes, leaving previous topics not completely discussed (Myers, 2009). While content analysis strives to make the meaning of words as clear as possible, conversation analysis does not pursue any precisely defined meanings of words or idioms. Content analysis assumes that the meaning is formed during the phase of the exchange therefore it is useful for the analysis of changes in the meaning that occur during the conversation. The researcher that tries to understand and explain the meaning of these phenomena has to participate in verbal interactions (Klein and Truex, 1995).

Discourse analysis focuses on the structure of a certain text where he also takes into consideration the social context where the text was created. Discourse analysis focuses on language that people use in everyday conversation or in writing (Myers, 2009). It tries to identify why a certain text was written as it was and not in some other way and why specific words are used in a specific word order (Johnstone, 2002). Although there are many different types of discourse analysis, the most frequently used discourse analysis focuses on the play of words where an important role is played by the use of metaphors, phrases and allegories. Discourse analysis emphasises that the text should be read through and interpreted several times (Klein and Truex, 1995).

Metaphor analysis enables systematic reflection on metaphors that help us and through which we can perceive, talk, think and function. The first step of the metaphor analysis is detection of metaphors in the text. Metaphors occur when the background of the meaning of words or phrases hides a certain deeper meaning and when their meaning arises from a certain, often abstract, psychological or cultural experience (Schmitt, 2005).

Hermeneutics is a study about explanation, interpretation and understanding of a certain text, symbol or sign. In a qualitative research, such as study case or ethnography, the researcher collects a large volume of data, such as notes, interviews, documents, field notes, 
sound recordings, descriptions of events, etc. After the collection, the researcher has to arrange, interpret and explain the collected data. This is where hermeneutics comes in handy because it enables analysis through which the researcher is able to interpret and understand the meaning of texts. Hermeneutics gives priority to the understanding of people. It tries to comprehend what people talk about, do and why they do it (Myers, 2009). It enables in-depth analysis of social and organizational situations in the field of business and is used also to study qualitative data in the field of business (i.e. information systems) and marketing (Myers, 2009).

One of the important advantages of semiotic analysis, compared to the content analysis, is that the researcher is not satisfied with superficial understanding of a certain text, but tries to use his analysis to penetrate and transcend the obvious observations. It is important to note that the researchers always interpret the signs or symbols differently therefore it is often necessary to resort to the arbitrary defined understanding of the problem (Bryman, 2004, as cited in Vogrinc, 2008). As the advantage of semiotics Myers (2009) points out the encouragement of the researcher to use various categories of data, whether in the form of a text, pictures or sound recordings, because semiotics encourages the researcher to decode the hidden meanings of signs and symbols. As its disadvantage the author indicates the excessive focus on the importance of symbols and signs and attributes a passive role to the people. Semiotics also requires a considerable level of researcher's creativity.

Narrative theory assumes that people form and live their lives through the narration of a story. Many theorists emphasised that people are without a doubt creatures that narrate stories (homonarrans). Stories are therefore a special form of interpersonal communication in a certain social context (Sremec, 2009). Narrative analysis can also be used for the analysis of data collected on the basis of interviews, where it is important that interviewees provide information that narrate the story, and that the analysis is open and encourages the interviewee to discuss new topics (Chase, 2005, as cited in Myers, 2009).

\subsection{QUANTITATIVE RESEARCH}

Quantitative research emphasizes numbers attributed with the value and which represent the basis for the establishment of their theoretical construct and scientific arguing of the functioning of the studied case. Examples of quantitative research (Myers, 2009):

- surveys,

- laboratory experiments,

- simulation,

- mathematical modelling,

- statistical analysis,

- econometrics.

Quantitative research allows generalization to the population with the help of an appropriate statistical sample and methods, therefore it is often used when we would like to research a certain topic with a large number of people or an organization. This research in intended to find the patterns of behaviour that occur in different situations. The weakness of quantitative research is that a lot of information is lost during the course of the research because a large part of social and cultural aspects is ignored on the account of generalization (Myers, 2009). 


\subsection{EXAMPLES OF QUALITATIVE AND QUANTITATIVE RESEARCH IN THE FIELD OF TOURISM}

We can generally say that qualitative approach is more appropriate for more demanding studies that are more complex and include a smaller sample and are based on descriptive variables, whilst quantitative research approach is based on numeric variables.

Qualitative research in the field of tourism is used to study:

- dimensions,

- concept forms,

- width diversity - values (e.g. what people do, their behaviour),

- tourist guidance,

- it includes question words, such as why.

Quantitative research in the field of tourism is used to study:

- relation, prediction and connection between positions,

- it includes question words, such as how much.

\subsection{SAMPLING}

Especially in quantitative research we have to take special care on the width of the sample (number of units included in the research) in order to guarantee the representativeness of the sample based on which it is possible to generalize the acquired results to the entire population of the studied units. Quantitative research often requires appropriate sampling of units because entire populations are too large to study and it is technically impossible to include them in the research (example: local population in the research of their attitude towards tourists). In case the population of the studied units is smaller (e.g. directors of the Slovenian natural spas) sampling is not required because the research can include the entire population.

In qualitative research, where the focus is put on studying of a smaller number of units or only an individual unit (person, organization, event, group) which we try to study it as comprehensive as possible, we should rather talk about selection than sampling. This does not mean that the method of selection of units to be studied is not important in qualitative research. It is of key importance that the sample is appropriate or relevant for the research, meaning that the selected units will help us acquire the desired information to answer our research questions or appropriately address the research objectives (Vogrinc, 2008).

\subsection{DIFFERENCE BETWEEN QUALITATIVE AND QUANTITATIVE RESEARCH}

The advantage of qualitative research is that it enables the researcher to identify and understand the decisions and actions of the participants in the research with consideration of the environment. It is only possible to understand certain actions and decisions of people with consideration of the entire environment and circumstances that help the researcher understand certain responses of these people. The reasons supporting qualitative research arise from the finding that people differ from the natural world with the ability to speak and it is exactly 
through conversation that the researcher can obtain information that would be lost in the large volume of quantitative data.

Qualitative research allows detailed analysis of an individual phenomenon or subject under investigation. Qualitative methods include smaller number of participants to which we can devote more time and attention, which is why we acquire more information from their longterm memory or the sub conscience with the help of projection techniques, such as role playing and interpretation of pictures. Such qualitative research is often performed for a certain new and completely unexamined area or for social, cultural and political aspects of people and organizations. The weakness of qualitative research is that it is often impossible to generalize the findings, acquired on the basis of an individual case, to the population, which means that any conclusion about the population on the basis of the sample is inappropriate (Myers, 2009).

Qualitative and quantitative research use different approaches, but can complement each other during the course of the study because it is possible to combine both techniques in order to get a comprehensive picture about a certain phenomenon (Neuman, 2003). Myers (2009) agrees with the opinion by Neuman and also believes that the study should include qualitative and quantitative methods and that both types of research can be perfect from the scientific point of view. Neuman (2013) defines qualitative and quantitative research as the process (triangulation) where a certain problem is viewed from different perspectives. In triangulation of methods, qualitative methods are mixed and complemented with qualitative methods and vice versa. We are talking about two different approaches where one of them follows natural science methods, whilst the other uses methods that are characteristic for humanistic methods and cultural studies (Mesec, 1997). Triangulation supports the principle that the research should be comprised of several different research methods, whether for collection of data or their analysis. Use of various sources is very widespread; researchers acquire information on the basis of the review of literature or with questionnaires and interviews. Simultaneous use of different research methods for the analysis in a single research is a lot more demanding because these methods differ significantly and require the researcher to have a wider knowledge of qualitative as well as quantitative research methods (Myers, 2009).

There is no difference between quantitative and qualitative approach in terms of their contribution to the spreading of knowledge about a certain problem or area. The difference is that in case of the quantitative approach we believe that an individual study adds only a small part to the bigger picture assembled on the basis of a large number of time-limited linear studies, whilst in case of the qualitative approach we believe that we can, within the framework of a single study composed of several small studies, gradually expand the range of findings to the extent where we can create an applicable theory (Mesec, 1997).

\subsection{DISCUSSION AND FINDINGS}

Analysis of qualitative data requires the researcher to study several different aspects. The first aspect is most certainly the aspect that the researcher should find the selected data analysis interesting or that it has to intellectually stimulate him in order for him to perform it in a satisfying manner. The approach to the analysis should also be harmonised with the researcher's philosophical aspects. In this way, the researcher drawing on the positivist approach will most probably use content analysis or analytical induction, the researcher 
drawing on the interpretive philosophy will use hermeneutics, semiotic or narrative analysis, whilst the researcher drawing on the critical approach will use discourse analysis. Research analysis also has to be harmonised with the selected qualitative method. If we use the fundamental theory, it is the most appropriate to continue coding instead of using the hermeneutics or discourse analysis. It is also important that we use the right type of analysis for the right type of data. If our data is in the form of a recorded conversation, we should use the conversation analysis, whilst conversation analysis is inappropriate for written or pictorial sources. Another important aspect when selecting the type of analysis is the possession of adequate knowledge and experiences (our or superior's) because this guarantees that the selected type of analysis will be performed in accordance with the standard practice or in an appropriate manner (Myers, 2009).

Besides the limited availability of sources and time limitations we also have to deal with the restrictions of the established ethical principles during the performance of the research. During the research we are often faced with moral dilemmas when we try to protect the participants of the research on one hand and conclude the research with publically published findings on the other. In his research, the researcher has to follow numerous ethical principles, such as the golden rule, honesty, avoidance of plagiarism and acquisition of consents and permissions for the publication of the results (Myers, 2009). The purpose of each research is not only the preparation of the article, but also its publication, whether in the form of an article, book or a paper in a conference. In such manner, our knowledge and experiences acquired in the research contribute to the awareness of other researchers that can use our research as a good basis for their own research. Today, a greater emphasis is given to the recording of a qualitative research than to its performance, especially in social sciences.

On the basis of its methods and data collection, quality research brings the possibility of an indepth understanding of the researched phenomenon and consideration of the aspects and factors that are often ignored in quantitative research especially because of the reduction of the volume of data and tendency to generalize. When we want to comprehend, understand and place a phenomenon in a wider cultural or social context. we can most certainly find an appropriate method in the range of qualitative methods and techniques. This method will open research possibilities and help us answer research questions in a successful and quality manner.

Qualitative research are studies that provide answers to general questions and represent the basis for the performance of empirical research. This is usually an initial research intended to study the positions or especially the theory which allows an advance quantitative research. Researchers perform a qualitative research alone with their knowledge representing basic standards. Reconceptualization, which is not represented or allowed in quantitative research, is extremely important part of this method. It is the most complex part of the qualitative research because the researcher decides about the standard by himself. Reconceptualization is performed by the researcher himself: if something he predicted or envisioned is not going according to his plans, he can change and re-establish the concept. This task can only be performed by the researcher who is a great methodologist, which is why methodological education is very important for qualitative research.

We have to understand that qualitative research is not just a conversation or interview where we show what we talked about. It is much more than that. Because of its high level of 
methodological complexity this type of research is more appropriate for already experienced researchers.

\section{Literature:}

Bastič, M. 2006. Metode raziskovanja. Maribor: Ekonomsko-poslovna fakulteta, Univerza v Mariboru.

Bryman, A. (2004). Social Research Methods. New York: Oxford University.

Chase, S. E. (2005). Narrative inquiry: multiple lenses, approaches, voices. In N.K. Denzin and Y. S. Lincoln (Eds). The Sage Handbook of Qualitative Research (3rd ed., 651-79. Thousand Oaks, CA: Sage.

Easterby-Smith, M., Thorpe, R. and Lowe, A. (2005). Raziskovanje v managementu. Koper: Fakulteta za management.

Maanen, J. V. (1983). Qualitative methodology. Beverly Hills: Sage.

Myers, D. M. (2009). Qualitative research in Business \& Management. Los Angeles, London, New Delhi, Singapore, Washington DC: Sage.

Mesec, B. (1997). Kvalitativna metodologija: izhodišča in načela. In Uvod v kvalitativno raziskovanje $v$ socialnem delu. Available from: https:// sites. google. com/site/kvalitativnametodologija/kvalitativna-metodologija/uvod-v-kvalitativnoraziskovanje-v-socialnem-delu-knjiga-1, January 7, 2017.

Miles, M. B. and Huberman, A. M. (1994). Qualitative Data Analysis: An Expanded Sourcebook (2nd ed.). Newbury Park, CA: Sage.

Mužić, V. (2004). Uvod u metodologiju istraživanja odgoja i obrazovanja. Zagreb: Educa.

Neuman, W. (2003). Social research methods: qualitative and quantitative approaches. Boston: Allyn and Bacon.

Radonjič, D. and Iršič, M. (2006). Raziskava marketinga. Ljubljana: GV založba.

Sagadin, J. (2001). Pregledno o kvalitativnem empiričnem pedagoškem raziskovanju. Sodobna pedagogika. Available from: http://www.sodobnapedagogika.net/?option=com_content\&task=view\&id=1501\&Ite mid=22, January 6, 2017.

Sremac, S. (2009). Integrativni pristup praktičnoj teologiji: Socijalna konstrukcija konverzijeprimer narativne analize svedočanstva konverzije kod bivših zavisnika. Kairos: Evanđeoski teološki časopis, 3(2), 339-364.

Straub, D., Gefen, D. and Boudreau, M.-C. (2004). "The ISWorld Quantitative, Positivist Research Methods Website". Available from: http://dstraub.cis.gsu.edu:88/quant/, January 6, 2017. 
Vogrinc, J. (2008). Kvalitativno raziskovanje na pedagoškem področju. Ljubljana: Pedagoška fakulteta, Univerza v Ljubljani.

Wolcott, H. F. (2005). Fieldwork vs. (just) being in the field. Fieldwork, 1, 43-58. London: Sage. 


\title{
CHAPTER 5
}

\section{PERSONAL RELATIONS IN SCIENTIFIC WRITING}

\author{
Author: Marko Koščak, Ph.D.
}

DOI: https://doi.org/10.18690/978-961-286-076-9.5

To learn how to learn is one of the basic human competencies. The complex qualification for mastering of personal learning includes the ability of decision-making, criticism and selfcriticism, developed thought processes, preserved curiosity, general knowledge, rich conceptual world and satisfactory level of previous personal knowledge. Qualification for independent learning is these days joined by digital qualification. This allows the student to independently decide, look for new ways towards knowledge (book, newspaper article, telephone conversation with an acquaintance, direct observation of a person possessing certain knowledge, archives, encyclopaedias, internet, consultation, trial and error, etc.). Some people still have not developed all of these abilities and characteristics and require the help of a mentor to stay on their individual path of education (Krajnc, 2012).

\subsection{MENTORSHIP}

The word mentor derives from the Greek legend of an experienced man called Mentor who was a friend of Odysseus. When he was going to the Trojan war, Odysseus entrusted him to take care for his home and to raise his son Telemachus. Mentor was Odysseus's counsellor and educator. The word mentor therefore stands for a leader, teacher, educator, counsellor of a young person with a lot of experience for life in the society.

Mentorship is still one of the very frequent forms of education. The period of study is when the student starts familiarizing himself with the topic he will have to deal with in his career in one way or another, the period when the student acquaints with or even studies this topic in a more profound and practical manner. The diploma thesis as the conclusion of an extensive study work therefore represents the peak of student's activities that should represent a professional challenge through which he is usually guided and directed by the selected mentor. The level of quality of the diploma thesis therefore also partially depends on the relationship between the student and the mentor. In order for this relationship to be as successful and as efficient as possible we believe that the development of a positive relationship between the student and the mentor is the most important. Successful mentorship requires appropriate initial conditions:

- In principle, the mentor should not turn down any mentorship, unless there is a valid limitation regarding how many mentorships an individual mentor may accept.

- The mentor should be convinced that learning will be successful and should have unlimited confidence in student's abilities.

- The mentor and the student have to be personally compatible at least in the sense that they are professionally attracted to each other. 
- There has to be mutual trust between them which is the prerequisite for an open communication.

The mentor should be able to get close to the student, he should try to identify himself with the student, and should get to know him in order to be able to draw out the student's undiscovered gifts and potentials and release all of his unexpressed personal capacities. There is usually a sensitive relationship between the mentor and the student. In a mentorship relation, the freedom of expression, progress in student's knowledge on one hand and suggestions by the mentor on the other hand, and also the boundaries of knowledge he sets should be in an optimal balance. As Chinese saying goes, the greatest happiness a person can experience is to meet an appropriate mentor because this guarantees student's personal development and progress.

Education in a relationship with the mentor is the most individualised path to knowledge and belongs amongst the most rational and effective forms of education. Mentorship is a dynamic social relationship. Tasks divided between the mentor and the student lead to the same goal: student's knowledge. In this relationship the mentor should adapt to the student and vice versa. The mentor makes the path to the goal shorter and compensates certain characteristic the student lacks. It often occurs that the student is not able to reach the end by his own because of his inability to take all decisions, such as: selection of sources, setting of the criteria for the satisfactory level of knowledge, mistake detection, etc., no matter if we are talking about a 15-, 30- or a 70-year student. He needs a mentor to help him reach the end. The mentor connects and coordinates various sources of knowledge and helps the student to discover new sources. He closely monitors what the student already masters and what are the following learning tasks. The mentor provides the student with a safe environment (Krajnc, 2012).

\subsection{ESTABLISHMENT OF A POSITIVE RELATIONSHIP BETWEEN THE STUDENT AND THE MENTOR}

There are many ways to establish a positive relationship between the student and the mentor which contributes to a general positive atmosphere at the faculty and to the success of its students. It is most likely that a positive relationship will lead to an effective consideration of the clearly defined parameters set for the preparation of the diploma thesis.

Students are humans and as such find it important that the mentor takes them seriously, encourages them and acknowledges their achievements. Establishment of constructive relationships with students is an uninterrupted process that includes everyday interactions between the student and the mentor. Important parts of such relationship:

- expression of positive expectations,

- constructive correction of student's work,

- establishment of professional confidence,

- expression of the interest in the student and his work,

- prevention and limitation of own frustrations and stress by the mentor. 
a) Expression of positive expectations to the student: High-level expectations and a positive expression of expectations regarding the results of the student's work will sooner or later lead to the fulfilment of these expectations. It is therefore a good thing that the mentor, in his interaction with the student, pays enough attention to the expression of high-level expectations in the academic field as well as more widely because these expectations are of key importance for the transformation of the student into an independently thinking expert who will in the future work in expert circles outside his faculty where he will (also) draw from the knowledge acquired at the faculty. It is also important that high-level expectations are expressed to all students not only to the most successful part of the student population. This process already starts when addressing students during lectures and practise.

b) Constructive correction of student's work: The purpose of the correction of student's work and formation of recommendations and suggestions is to make the student reflect on the performed task, determine the reasons for its necessity and to understand its content in a way that such corrections and suggestions will no longer be required in the future. The suggestion of amendments should be professional and in no way directed against student's dignity. It is very appropriate if the discussion takes place in a room where the mentor and the student can talk privately without the unnecessary audience. The mentor should provide the student with mentorship he would like for his own child. It is important that the discussion is always calm and constructive and that the mentor and the student do not surrender to frustrations.

c) Establishment of student's professional confidence: Professional confidence is quite underestimated according to its influence on the successful and effective relationship between the student and the mentor. Every student's goal is or should be to achieve high-level results in his area of expertise which consequently impact on the formation of his professional and wider personal identity. Mentor's task is to promote professional confidence and to establish it on the basis of professional achievements of an individual student or even a group of students during practise, study year, etc. Acknowledgement of student's achievements can be, for example, shown with a display of his work, oral praise during lectures, spreading of information about the achievement to other students and professors, and also with the praise of the student's progress and not only his excellent achievement.

d) Expression of the interest in the student and his work: Expression of the interest is one of the most effective ways to establish a positive relationship between the student and the mentor. The mentor should greet the student, sincerely listen to him and show understanding for his perception of the set tasks and work. Such approach has an impact on the disciplined performance of the set tasks and the following of the established methodology.

\section{e) Prevention and limitation of own frustrations and stress by the mentor:}

Frustration and stress are inevitable phenomena occurring in the professor's or mentor's career. We should not ask ourselves whether the mentor will get frustrated and under stress, but when and how he will react. Signs of frustration and stress include nervousness and tendency to take irrational decisions. The mentor should primarily be able to recognize the signals in him in order to be able to successfully manage them. The techniques for the prevention of frustration and limitation of stress should be appropriate for every individual because a certain technique that what works for one professor does not necessarily work for another. It is also 
important that the mentor reacts properly to the potential expressions of student's tendencies towards him. In any event, the mentor should consistently analyse student's work and not his attitude towards work.

\subsection{PREPARATION OF THE FINAL PAPER}

This topic was thoroughly discussed by Vasja Vehovar from the Faculty of Social Sciences of the University of Ljubljana which is why some of the views and considerations will be quite similar to what he had to say about this topic.

A diploma thesis candidate usually waits for the faculty where he studies to publish the topics for diploma theses. Student self-initiative is of course possible and even desired which in this case means that the student visits the mentor with an already established suggestion regarding the topic of his diploma thesis even before the formal publication of topics by the faculty or the potential mentor. In any case, the student should visit the professor where he should select an available topic or where the professor/mentor would confirm the available and selected topic. The student should select the professor or the topic on the basis of a certain subjective criterion of the appeal of the topic and perhaps the professor. It is in any case reasonable that the student hurries up and selects a good topic and desired mentor while they are still available.

\subsubsection{Selection of the mentor for the preparation of the diploma thesis}

For the preparation of the diploma thesis with a serious content, the topic is certainly more important than the mentor. It is especially important that the student finds pleasure and interest in the selected content. Nevertheless, it is recommendable that the student takes into consideration the following factors:

- The student should ask older students/graduates about how the desired professor wishes the process of preparation of the diploma thesis to take place, but he should not take these information too seriously because they will be very subjective. He should check these information personally in a direct communication with the mentor and should then form his own opinion which is more important than the first one. It is even more important that the student finds the topic really interesting and that he feels good during the initial communication with the professor. There are of course differences in the level of an individual professor's engagement in the student's topic and how much time he will reserve for the discussion. A higher level of engagement by the professor is valuable and positive, but can sometimes involve excessively formalistic demands. The biggest differences can perhaps be found in the view of the prompt responding. E.g. how quickly the professor responds to e-mail and how fast he reads the draft thesis. This is an important fact for the student who should take it into consideration in his final decision about the selection of the mentor. Prior to the final selection of the mentor (and topic) it is recommendable to review previous topics by the potential mentor and diploma theses in the student's field of interest. The student can thereby create his own impression and image about how his diploma thesis should look like. At 
the same time he will also get an idea regarding the field he would like to study in his work (Vehovar, 2008).

- Younger mentors, who were not in a role of the mentor a lot of times, are for the most part more enthusiastic and will probably pay a lot more attention to the student, have more time and will be available more often. At the same time they might be more precise and more demanding. It is also possible that they will lack a certain knowledge and experiences (and perhaps understanding and generosity) that come with years and are especially valuable in case of potential complications.

\subsubsection{Selection of the co-mentor for the preparation of the diploma thesis}

In case of diploma theses with specific content that demand narrow professional knowledge, the student cannot expect that the professor masters several professional fields (e.g. professor from the field of marketing might not entirely master the field of branding, etc.). Similarly, certain topics are so complex that their quality treatment requires cooperation of two specialists. The candidate can in principle leave the final judgement to the mentor without any worries. If the mentor estimates that he is unable to cover the selected field, he will, due to his professional and ethical responsibility, decide for co-mentorship and also propose an appropriate colleague. Especially proactive students will perhaps propose co-mentorship themselves which is sometimes very useful. The student has to be aware that co-mentorship can make the entire process somewhat more complicated and can eventually even prolong the preparation of the diploma thesis. On the other hand co-mentorship in most cases raises the level of quality of the diploma thesis and enriches the student's experience.

\subsubsection{Communication between the student and the mentor}

The first meeting is in most cases extremely important because it defines the relationship, motivation (right or wrong), topic, etc. From the perspective of the student it is, during the first meeting, recommendable to especially explain the following:

- It is useful to ask the professor at the very beginning: How long will the entire process take, how many personal interviews will it take or are usually necessary, what problems does the professor most frequently encounter, what is the telephone, electronic, personal or written communication like and what is the professor's response time (what can the student expect, information regarding the leave, absence, and how should the student act in case of the professor's unresponsiveness)?

- The student should review previous diploma thesis mentored by this professor and find out which one is particularly good. It most certainly does not hurt if the student takes into consideration the form of such diploma thesis and uses it as an example, especially in terms of formality. It is reasonable to get the professor's reflection on this diploma thesis, e.g. how does he evaluate it, did it require a lot of work, is the level of its quality adequate to serve as a model, in what direction could it be upgraded, etc. Individual professors themselves usually suggest to the candidate the examples of diploma theses and examples of good practice from their previous mentorships. 
In any case, the student should as soon as possible - if possible at the very beginning - be able to clearly articulate to the professor in a single sentence what is the main purpose of the diploma thesis, what he would like to achieve and how he would like to approach the thesis (Vehovar, 2008).

\subsubsection{Cooperation of the student and the mentor}

As we already mentioned, the initial meeting with the mentor represents the key step in the preparation of the diploma thesis. Identification of the topic and formulation of the application often requires quite a few meetings or interactions. Mature and well-thought over topic is then recorded on the application or disposition that requires an advance formal confirmation by the mentor. It often occurs that 2-3 interactions are needed before the finalization of the application. This is usually done or can be arranged also via e-mail. In certain cases - when issues were not previously fully and well agreed upon - the application itself requires several personal interviews and coordination.

After the work is planned (not necessarily also registered) the student starts dealing with the theory and later with experimentation. This framework sometimes requires interaction with the mentor, whether via e-mail, telephone (more practical and effective and often ignored) or in person, depending on the complexity of the issues and the way the professor works. The basic rule is the following: As soon as any problems, confusion or changes of the plan occur even more important, as soon as the students starts to think whether he should perhaps contact his mentor - this is the sign that the student should contact his mentor immediately. It can happen that the student can head in the wrong direction which causes him to lose a lot of time.

\subsubsection{Steps in the preparation of the diploma thesis}

The number of interventions/interactions with the mentor can vary widely during this phase. Approximately half of the diploma theses actually require very few or even no interventions/interactions, whilst some of the diploma theses require much more. This process usually includes at least three milestones that require mentor's feedback:

1. When a substantial part of the theory or experiments are studied through (e.g. few dozen hours) it is reasonable to prepare a »working draft« on a couple of pages as soon as possible:

- »working draft « (1-2 pages with the description of the content, of course only if it was significantly changed in relation to the application or disposition, or if there was no application at all - otherwise all of this is unnecessary because it is included in the application),

- first draft of the introduction (at least one or two pages to show how student's style of writing; in exceptional circumstances - only upon agreement - longer text can be written, e.g. the entire theory),

- table of contents and literature which can be the same as in the application or disposition if there is one and if this was accepted by the mentor. 
The mentor then reviews all of this and provides a response. If there are no complications, a special (personal) reaction by the mentor is not necessary at this point. E-mail confirmation is enough to confirm that there are no complications and that the student should continue with his work.

2. The following key step is approx. 10-30 pages of text which should be written as soon as the student studies through an adequate part of the theory or experiments and when it is clear that further deepening will not significantly change this introductory part of the diploma thesis. In case of great independence, mutual knowledge and trust and good experience with the first point, the student can also write the entire diploma thesis (this rarely happens and is in principle discouraged by many mentors). The cited text is important because the student's style of writing is finally evident. The mentor can now assess the analyticity and width and the potential substantive problems of the diploma thesis (depending on the level of independence, maturity, level of articulation and complexity of the topic). The student can then prepare the entire draft without any additional interactions, whilst the professor can, in this process, asses and suggest that more or less thorough interactions, electronic or personal, will be required. On this basis, several partial drafts can be exchanged until reaching the final text. In case of more complex issues that require interaction, it is by far the most effective to review and comment on the drafts in person. Personal conversation can further explain the arguments of one or the other side and makes the final decision about how to proceed more coordinated and based on a consensus between the student and the mentor. More extensive commenting of the diploma thesis (e.g. in a form of »following the changes «) is usually not the most appropriate for making comments about the content (it is above all appropriate for making formal comments and comments about the language) because there is no interaction. The mentor therefore occasionally spends twice as much time, first to read and mark, and then to make comments or for interpretation in a personal interaction. If everything is planned well, the mentor should, at this point, have no significant comments (Vehovar, 2008).

3. The final draft can be prepared on the basis of a single feedback interaction regarding the initial draft (2), but may - as indicated above - also require intermediary interactions (electronic, telephone, personal). If the topic is well defined and if the student is independent and has a lot of work experience, the process does not require or requires only a minimum amount of intermediary interactions. In any case, the final draft should be systematically reviewed by the mentor. In case of a minimum amount of comments regarding the language, comments in the text might be enough, whilst in case of complex issues with the content it is reasonable to perform the review in person. In case of simple issues, the experienced mentor can read through the text in the presence of the student, otherwise the mentor should read it through in advance and provide comments during the meeting. In case of a small amount or no comments, the process of writing concludes, otherwise additional interactions are required until the mentor approves the work (Vehovar, 2008).

\subsubsection{Duration of the process and the number of interactions with the mentor}

The duration of the process and the number of interactions with the mentor depend on several factors: selected topic, available professional literature, student's quality and consistency when taking into account the instructions provided by the mentor, quality and depth of corrections 
by the mentor, available time, etc. During the review of the duration it is advisable to also get familiar with the official provision of the rules by the Faculty of Tourism regarding the time until which the mentor has to review the text of the diploma thesis and provide his comments. It is of course always better to discuss the issues and to mutually agree upon reasonable deadlines that allow optimal performance of the set work. In principle, the mentor can (with written argumentation) also reject cooperation due to other reasons. In the process of graduation, the student is also entitled to a single interruption of the cooperation with the mentor and to file his application with another mentor.

\section{Literature:}

Krajnc, A. (1979). Metode izobraževanja odraslih. Ljubljana: Delavska enotnost.

Krajnc, A. (2006). Kdo so bili moji mentorji? Kdo mi je lahko mentor? Andragoška spoznanja, 13(4), 31-39.

Krajnc, A. (2012). Individualizacija izobraževanja vodi v mentorsko gibanje Znaš, nauči drugega. Andragoška spoznanja, 18(2), 19-28.

Vehovar, V. (2008). Priporočila za diplomsko delo. Available from: http://vasja.ris.org/c/374/Priporocila_za_pisanje/?preid=2, November 23, 2016. 


\title{
CHAPTER 6
}

\section{LANGUAGE AND THE STYLE OF WRITING}

\author{
Author: Barbara Pavlakovič
}

DOI: https://doi.org/10.18690/978-961-286-076-9.6

The chapter about the language and the style of writing primarily discusses what is linguistically appropriate, nice and good in scientific writing. The linguist Jože Toporišič (2008, p. 23) said that a message is only good when the »[...] real or imaginary reality found its most perfect wording, i.e. when the reality was captured with linguistic means in its most perfect typicalness $[\ldots] \ll$. This means that a message is the most effective when the receiver of the message is able to recognize the true purpose of communication. Preparation of such text therefore requires some practice and a well-developed sense of language. Toporišič (ibid.) describes it as a subconscious management of criteria and rules about the use of linguistic means. The following sections include some of the guidelines about the proper use of the language for scientific communication in the field of tourism.

\subsection{GENERAL CHARACTERISTICS OF SCIENTIFIC WRITING}

According to the type of text, seminar and final papers belong amongst professional texts (Gomboc, 2009, p. 148). What they have in common with other professional texts is that they are intended for recipients who are interested in the presented content or who deal with the discussed topic themselves. Another characteristic is that these texts are prepared by experts in a certain field of expertise who use a lot of professional expressions and terms in their communication. This means that the recipient requires some previous knowledge to understand such texts.

Professional texts can be divided into science and popular science texts (ibid., p. 150). Seminar and final papers can be included amongst scientific professional texts. Like it is characteristic for scientific texts, preparation of seminar and final papers includes more complex expressions, definitions and professional terminology. Such writing is also characterised by verbless sentences, use of the passive, and precise and unambiguous description of findings. Author's objective positions are very important for such writing.

Objectivity of a certain text is also expressed through the use of the appropriate verb form (verb as a word that names the action, situation, occurrence, perception, existence) (ibid., p. 93). In order to ensure objectivity, the paper should be written in the first-person plural. Example of all persons and the number of verb forms is shown in Table 3. 
Table 3: Persons and number of verb forms

\begin{tabular}{||c|c|c|c||}
\hline Person/number & Singular & Dual & Plural \\
\hline $\mathbf{1}^{\text {st }}$ person & I conclude. & $\begin{array}{c}\text { The two of us } \\
\text { conclude. }\end{array}$ & We conclude. \\
\hline $\mathbf{2}^{\text {nd }}$ person & $\begin{array}{c}\text { You } \\
\text { conclude. }\end{array}$ & $\begin{array}{c}\text { The two of you } \\
\text { conclude. }\end{array}$ & You conclude. \\
\hline $\mathbf{3}^{\text {rd }}$ person & $\begin{array}{c}\text { He/she/it } \\
\text { concludes. }\end{array}$ & $\begin{array}{c}\text { The two of them } \\
\text { conclude. }\end{array}$ & $\begin{array}{c}\text { They } \\
\text { conclude. }\end{array}$ \\
\hline
\end{tabular}

Seminar and final papers should be written in the Slovenian language (exceptions where they can be written in a foreign language are defined in the Pravilnik o postopku priprave in zagovora diplomskega dela (Rules on the procedure of preparation and defence of the Diploma thesis) of the graduate study programme of the Faculty of Tourism of the University of Maribor and in the Pravilnik o postopku priprave in zagovora magistrskega dela (Rules on the procedure of preparation and defence of the Master's thesis) of the post-graduate study programme of the Faculty of Tourism of the University of Maribor). When writing the scientific text we should avoid the use of foreign words especially where an established Slovenian term is already in use. If this is possible we should find appropriate Slovenian terminology. Toporišič (2008, p. 25) says that the use of foreign words does not contribute to the diversity or better understanding of the text. On the other hand, the use of local terms can contribute to a wider range of terminology and professional words in the local language which consequently strengthens the field of tourism itself.

According to the fact that there is a wide range of employees with different education working in the field of tourism it is extremely important that we take care for education also in the field of the development of intellectual knowledge. A step towards such development is learning of scientific writing and the consequent spreading of knowledge in the field of tourism. Scientific writing in the field of tourism follows three basic instructions about writing. The written work should be (Sternad, Boršič and Tominc, 2013, p. 55):

- clear (the governing theme of the text should be written smoothly and reasonably from the beginning to the end);

- concise (text should be concisely written without the repetition of already written and without the unnecessary, substantially unimportant supplements);

- coherent (content of the text should be written in a coherent manner where the paragraphs and chapters logically follow one another and continue the presented though and should not only cite non-coherent paragraphs).

The text should be written in an argued manner and reinforced with quotations. It is unacceptable to solely state quotations by various authors - linking elements in the text should represent our thoughts, cue words, reflection. The text should be divided into chapters and sub-chapters that represent reasonably closed units of several paragraphs (paragraphs are reasonably closed units of several sentences). An individual chapter can include several sub- 
chapters with texts that take up at least one half of the A4 page. In case of shorter chapters we should consider whether a new chapter is really required or can we include this content in a different chapter. The text should follow the development of the presented idea therefore the content of the chapter should correspond with the title of the chapter.

Seminar and final papers are public works. This means that they are intended and available to a wider public. We can find final papers in the library of the faculty, whilst seminar papers are often prepared in cooperation with an organization that would like to get a view of its work by the students. Because written works are available to the public we should take care that to make them linguistically correct. This means that we should follow the orthography rules and language style when writing our papers. Some of the most common orthographic predicaments will be presented in the following sections.

\subsection{PUNCTUATION MARKS}

Punctuation marks are an important part of the use of the language because they connect words, phrases, parts of sentences or sentences, and also indicate the text flow and mark the meaning of the end of a sentence (Gomboc, 2009, p. 120). Punctuation marks are divided into final and non-final. Final punctuation marks include full stops (.), exclamation marks (!) and question marks (?) that are not separated with a space between the punctuation mark and the word on the left (no space between the word and the punctuation mark). Final punctuation marks also include ellipses (...) and dashes (-) that are final punctuation marks separated with a space (space between the word and the punctuation mark). In scientific writing we should avoid the use of exclamation marks, ellipses and dashes because they are associated with an emotional connotation or indicate an unfinished thought which we should avoid in order to ensure objectivity in scientific writing.

Example:

- FULL STOP: Tourism is an important branch of economy.

- EXCLAMATION MARK: Hello!

- QUESTION MARK: How would you explain the connection between the two variables?

- ELLIPSIS: We were not able to find that out ...

- DASH: If we knew -

Non-final punctuation marks include two-part punctuation marks, such as dashes (-), quotation marks (» «) and brackets ( ). The group of one-part non-final punctuation marks includes commas $($,$) , semicolons (;)$, colons $(:)$, ellipses $(\ldots)$, dashes $(-)$ and hyphens $(-)$. Quotation marks and brackets are written without the space between the punctuation mark and the word (first part in contact with the word on the left and the second part on in contact with the word on the right). Commas, semicolons and colons are punctuation marks that are not separated from the word with a space. Ellipses and dashes are punctuation marks that are not separated from the word with a space. The exception in case of the hyphen (ibid., p. 125) is its use instead of the words 'from' and 'to' where the dash becomes a punctuation mark that is not separated from the words on both sides. The second exception is its use as the mathematical minus when the dash becomes a punctuation mark that is not separated from 
the word with a space on the right side. Hyphens as short dashes are in most cases punctuation marks that are not separated from the word with a space on either side and are used in certain foreign names and phrases, between two surnames and between two parts of a double geographical name (Dobrovoljc and Jakop, 2011, p. 108).

\section{Example:}

QUOTATION MARK AND BRACKET: As indicated by the definition of tourism: »Tourism is the aggregate of relations and phenomena that come into an existence because of travelling and accommodation of people where the place of accommodation is not their main or permanent residence nor place of employment« (Mihalič, 1998, p. 14).

COMMA: According to statistical data the highest number of overnight stays in 2015 was recorded in municipalities of Ljubljana, Piran, Bled, Kranjska Gora and Brežice.

COLON AND SEMICOLON: In order for the diet to be healthy it should be:

- balanced and include an optimal volume of nutrients;

- safe and not cause any poisoning of the organism;

- protective, in order to protect against civilization diseases.

DASH: Our municipality has a very rich history - the very beginnings of tourism activity can be detected already in the $18^{\text {th }}$ century. // This museum has long opening hours since it is open from 8a.m.-20p.m. // Winters in Finland are very cold, The usual temperature falls to $-20^{\circ} \mathrm{C}$.

HYPHEN: In Slovenia, the railway network was developed during the Austro-Hungarian Empire. We visited the German spa town of Baden-Baden. We did not plan to stop in Šmarje - Sap.

\subsection{LARGE AND SMALL INITIALS}

In principle, all words are written with lowercase letters, whilst large initials are reserved for the following (the most frequently used) cases (Gomboc, 2009, p. 72):

First word of the sentence: Tourism industry is growing.

Beginning of the quoted sentence or direct speech: As indicated by the definition of tourism: »Tourism is the aggregate of relations and phenomena that come into an existence because of travelling and accommodation of people where the place of accommodation is not their main or permanent residence nor place of employment« (Mihalič, 1998, p. 14).

Proper nouns and names of animals: David Novak, Tjaša, Slovenija, Zdravljica, Zemljan ...

Possessive adjectives derived from proper nouns: Davidov, Tjašin, Slovenčev ...

Proper nouns may be personal names, names of things and geographical names. Personal names include names of people and animals, surnames and nicknames (David Novak, kuža Fifi, Rdeča kapica), names of mythological beings (Bog, Alah, Apolon) and names of residents (Ljubljančan, Slovenka, Azijec).

Names of things are used to name companies, institutions, groups, books, artwork, premises, vehicles, trademarks, etc. (Gomboc, 2009, p. 74). The first word of names of things is written with a large initial, whilst other words are written with small initials (except for proper nouns). 
Names of things also include names of tourist facilities and museums, such as names of hotels, holiday homes, museum facilities and their branches (Dobrovoljc and Jakop, 2011, p. 77).

Example: Slovenska turistična organizacija, Mestni muzej Ljubljana, Koča pri Triglavskih jezerih, Grand hotel Bernardin, Republika Slovenija, revija Turizem, Dnevi piva in cvetja, etc.

One-word geographical proper nouns are written with large initials (Posavje, Avstrija, Ljubljana), whilst multi-word geographical proper nouns are written in accordance with orthographic rules (Gomboc, 2009, p. 73). These nouns are dividen into settlement and nonsettlement names. Settlement names indicate names of cities, squares, villages and small villages. All of these words are written with large initials, except for the non-first prepositions and words mesto, vas, trg, selo.

Example: Murska Sobota, Loški Potok, Šmarje pri Jelšah, San Francisco, Novo mesto, Nemška vas etc.

Non-settlement names are the names of streets, city quarters, regions, countries, continents, rivers, seas, mountains, valleys, planets, etc. (ibid., p. 74). The first word of the name is written with the large initial, whilst other words are written with small initials, except for proper nouns.

Example: Rožna dolina, Slovenske gorice, Indijski ocean, Južna Amerika, etc.

\subsection{PREPOSITIONS}

Prepositions are shorter words that determine precise relations within the sentence (Gomboc, 2009 , p. 100). It often occurs that certain prepositions with the same function are exchanged, however specific grammatical rules apply for such prepositions.

This leads to the exchange of prepositions s and z. Preposition s is used in front of voiceless obstruents (all conconants in the sentence: Ta suhi škafec pušča), whilst the preposition $z$ is used in front of vowels, consonants and voiced obstruents (all other characters) (ibid., page 51). The next example are prepositions $h$ and $k$. The preposition $h$ is written in front of the words starting with $\mathrm{k}$ or $\mathrm{g}$, whilst the preposition $\mathrm{k}$ is written in front of all of the other sounds (ibid. p. 51).

Example: z nečakom, s kolesom, h kresu, k drevesu.

Prepositions are also used when indicating movement. The preposition $v$ is used to indicate movement into something, whilst the preposition iz is used to indicate movement out of something. When we would like to indicate movement on top of something we use the preposition na, whilst prepositions $\mathrm{s}$ or $\mathrm{z}$ are used to indicate downward movement (ibid., $\mathrm{p}$. 100).

Example: Potujem v Italijo. $\rightarrow$ Vračam se iz Italije. / Šel sem na morje. $\rightarrow$ Pošiljam ti pozdrave z morja.

\subsection{NUMBERS}

Writing of numbers should also follow grammatical rules. Numerals under 100 and hundreds are written together, whilst other numerals are written apart. Ordinal, collective and multiplicative numerals are also written together. If these numerals are written with numbers 
we should use a hyphen (Gomboc, 2009, p. 70). We should also take care when writing the date. Behind the numbers for the date and the month we should write a full stop followed by a space. Numbers under 10 should not include the zero.

Example:

- sedeminosemdeset, tristo dve

- stodvanajsti, stotisočer, petkraten, osemnajstletnica

- 18-letnica

- 16. 6. 2016 // 9. 8. 2017 // 29.11. 1958

\subsection{SPECIAL CHARACTERS IN THE TEXT}

Scientific texts often also include other written signs or non-character signs. Such signs include the sign for percentage (\%) and per miles (\%o) and monetary units $(€)$ that are written apart which means that a space is placed in front of the sign (Dobrovoljc and Jakop, 2011, p. 55).

\section{Example:}

V raziskavi smo odkrili, da ima $35 \%$ anketirancev večjo plačo od $1.500 €$ bruto.

With a quick overview of the style of scientific writing in the field of tourism we would like to promote the language culture of students and future workers in the field of tourism. Language culture is defined as following the language rules (narrow meaning) and taking care for and development of the standardised written language (wider meaning) (Kalin-Golob, 1996, p. 40). Our aim is to establish a well-developed and cared for language in the field of tourism.

\section{Literature:}

Gomboc, M. (2009). Mala slovnica slovenskega jezika: priročnik za šolo in vsakdanjo rabo. Ljubljana: DZS.

Dobrovoljc, H. and Jakop, N. (2011). Sodobni pravopisni priročnik med normo in predpisom. Ljubljana: Založba ZRC.

Sternad, S., Boršič, D. and Tominc, P. (2013). Navodila za izdelavo pisnih del na Ekonomskoposlovni fakulteti. Maribor: Ekonomsko-poslovna fakulteta.

Toporišič, J. (2008). Stilnost in zvrstnost. Ljubljana: Založba ZRC, ZRC SAZU.

Kalin-Golob, M. (1996). Jezikovna kultura in jezikovni kotički. Ljubljana: Jutro. 


\title{
CHAPTER 7
}

\section{CITATION OF LITERATURE AND SOURCES}

\author{
Author: Maja Rosi \\ DOI: https://doi.org/10.18690/978-961-286-076-9.7
}

\begin{abstract}
When writing scientific professional papers we often rely on the information and ideas by other authors, which is why we should strictly separate the text by the author from the findings, thoughts, ideas, data, illustration and other information by other authors. The author of the scientific and professional paper may use definitions of the phenomena, scientific facts, ideas, data, information, illustration and other information by other authors, but should always clearly and in the established manner cite whose information he used and the sources. Citation of sources adds to the credibility of our work and arguments and allows the reader to find additional information about the selected topic.
\end{abstract}

When citing sources we can use various styles of writing, such as APA (American Psychological Association), Chicago, Harvard, ACS (American Chemical Society), MLA (Modern Language Association), etc. Each field of expertise usually demands a certain style of writing. For example, the APA style is used predominantly in social sciences, business and educational sciences, MLA style is used in humanistic sciences, AMS style is used in mathematics and computer science, ACS style is used in chemistry, etc. Use of the appropriate style depends also on the instructions by individual publishers of publications where we would like to publish our paper. For example, publications in the field of political sciences demand the use of the APA style when simultaneous citation of sources is required (within the text) and the Chicago style when citation of sources is required in footnotes or final notes (Lipson, 2011, pp. 4-6). These instructions should be followed if we would like to publish our paper in their publications.

In social sciences we most frequently use the APA (American Psychological Association) style to cite sources whose standards also apply for scientific articles, professional articles, seminar papers, reports, and diploma thesis and master's thesis at the Faculty of Tourism of the University of Maribor. The rules for citing sources in accordance with the APA standard are summarised from the handbook entitled Publication manual of the American Psychological Association - 6th edition, 2010 (for more information see: www.apa.org) and adapted for writing of written and final papers at the Faculty of Tourism of the University of Maribor.

\subsection{WHEN IS IT NECESSARY TO CITE THE SOURCE?}

The source should be cited when a certain work of another author (his ideas, theories, studies) has a direct impact on our work. Work by other authors allows us to acquire the basic information, helps us verify the established hypotheses and/or research questions, and provides important definitions and data. Citation of sources by other authors means that we personally read through their work and that we agree or disagree with author's ideas, and that we acknowledge the effort authors invested in their written paper. 
The number of cited sources differs according to the content and purpose of our written work. As a general rule, it is impossible to cite too many sources. When summarizing ideas, thoughts, data, figures, tables, graphs and other information, even if only one sentence or though by another author is summarised, this has to be properly indicated. Otherwise this would constitute plagiarism or theft of intellectual property.

»Authors should not present work by other authors as it was their own! «(APA, 2010, p. 16). In order to avoid problems caused by plagiarism it is necessary to consistently follow the rules regarding the citation of sources which are presented in the following sections.

We can talk about citation of sources in case of:

1. literal citation from a certain source (letter by letter copies/transcriptions),

2. summarization or transformation of an information from a certain source with our own words.

\subsubsection{LITERAL CITATION FROM THE SOURCE}

In literal citation of another author's text we should use quotation marks (" " or » «) where the text has to be completely identical to the original. If the original includes italic fonts, our text should also include it. If we leave out certain words or sentences in our citation, we have to indicate this by using ellipses. Literal citation, which has to be used in accordance with the rules, is therefore allowed in final papers. It shows the authors »maturity« in the acceptance of sources by other author's.

In case of literal citation it is necessary that the text includes the indication of the author, year of publication (and page of the quoted text or the number of the paragraph in case of unnumbered works) and to include the source in the list of sources and literature.

\section{Example:}

In the interpretation of this phenomenon we can help ourselves with the definition by authors Žigoni and Konečnik Ruzzier (2014, p. 78) who say that »mountain-biking destinations represent a sub-group of adventure destinations or destinations whose offer is based on the natural environment, however the needs and requirements of their target group are specific and differ significantly from the needs of other visitors « which additionally reinforces this topic.

If the literal citation is put at the end of the sentence, it should be written in the following form:

I agree that »mountain-biking destinations represent a sub-group of adventure destinations or destinations whose offer is based on the natural environment, however the needs and requirements of their target group are specific and differ significantly from the needs of other visitors« (Žigoni and Konečnik Ruzzier, 2014, p. 78).

\subsubsection{SUMMARIZATION}

We can talk about summarization when we reasonably summarize or transform a certain information, part of the sentence, thought by another author from a certain source with our own words in order to better integrate it in the context of our text. 


\section{Example:}

Eco $(2003$, p. 46) believes that in the ideal case the thesis and the counsellor are selected near the end of the second study year because we are then already familiarised with the content of individual professional subjects.

In ideal case, the thesis and the counsellor are selected near the end of the second study year because we are then already familiarised with the content of individual professional subjects (Eco, 2003, p. 46).

When citing sources, we should distinguish between:

1. SOURCES WITHIN THE TEXT (sources located in the text which inform the reader about which information was borrowed/summarized and about the author of such information),

2. LIST OF SOURCES (a list located at the end of the text which informs the reader about which sources were used in the preparation of the text, and which provides complete information about the used sources).

\subsection{CITATION OF SOURCES IN THE TEXT}

Sources are cited in the text in case of summarized thoughts, statements, data, figures, tables or graphs by other authors. Sources should be cited immediately and should be simultaneously alphabetical included in the list of sources located at the end of our text. It is important that every source from which we cited or summarized a certain text is located in the list of sources. It also applies vice versa: Every source included in the list of sources should be cited in the text.

In the following sections we will present the examples of citation of sources in the text.

\section{Single author}

When we cite texts by a single author we should be careful to indicate the surname of this author, the year of publication and the page (if possible) at the appropriate place in the text. Citation should not include suffixes, such as Ph.D., Mrs., Mr., etc.:

Walker (2000, p. 20) compared the response times ...

In the study about response times ... (Walker, 2000, p. 20).

When the surname of an author appears in the same way as this is indicated in the first example we should only indicate the year of publication and the page in brackets, whilst summarization from the second example should indicate the surname of the author, year of publication and the page (separated by commas) in brackets at the end of the summarized text. Brackets are followed by a full stop.

In case of the combination of the first and the second type of source citation, special care should be paid to the way the source is indicated:

Walker (2000, p. 20) compared the response times ... The study also showed that the response times ... (Walker, 2000, p. 20).

or

In the study about response times ... (Walker, 2000, p. 20). Walker (2000, p. 20) further concludes that ... 


\section{Two authors}

When a certain work was prepared by two authors we should always indicate both authors in the text. There should be a conjunction word »and « located between the surnames of both authors:

Walker and Saleh (2000, p. 25)

or (Walker and Saleh, 2000, p. 25)

\section{Three to five authors}

First citation should include all authors with the conjunction word »and « located between the penultimate and the last surname. The following citations should only indicate the surname of the first author followed by the abbreviation »et al.« or »etc.«. In any case we should use a uniform marking throughout the text and the markings »et al.« or »etc.« should never be combined in the same text.

First citation of the source:

Wasserstein, Zappulla, Rosen, Gerstman and Rock (1994, p. 32) determined ... or (Wasserstein, Zappulla, Rosen, Gerstman and Rock, 1994, p. 32)

Second citation of the source:

Wasserstein et al. (1994, p. 32) determined ...

or (Wasserstein et al., 1994, p. 32).

EXCEPTION: If we quote from several sources with several authors where the surnames of first authors and the year of publication are the same, which is why it is impossible to distinguish between different sources, we should indicate surnames of all authors up to the surname of the first different author:

Ireys, Chernoff, DeVet et al. (2001, p. 51) and Ireys, Chernoff, Stein et al. (2001, p. 51)

\section{Six or more authors}

When there are six or more authors, each citation should only include the indication (also for first indication) of the first author followed by »et al.« or »etc.«:

Kosslyn et al. (1998, p. 121) or (Kosslyn et al., 1998, p. 121)

EXCEPTION: If we quote from several sources with several authors where the surnames of first authors and the year of publication are the same, e.g. Kosslyn, Koening, Barrett, Cave, Tang and Gabrieli (1996, p. 14) and Kosslyn, Koening, Gabrieli, Tang, Marsolek and Daly (1996, p. 21) and is therefore impossible to distinguish between different sources, we should indicate surnames of all authors up to the surname of the first different author:

Kosslyn, Koenig, Barret et al. (1996, p. 14) and Kosslyn, Koenig, Gabrieli et al. (1996, p. 21) 


\section{Organization or group as the author}

Names of organizations, groups, associations, government agencies, study groups, etc., should be indicated whenever they appear as authors in the text. The first citation of the source usually includes the full name of the group, whilst further citations should include abbreviations. Abbreviations should be used reasonably with the simultaneous observation of the rule that they should provide adequate information in the text in order for the reader to be able to find them in the list of sources.

First citation of the source in the text:

National Institute of Mental Health (NIMH, 2003)

Second citation of the source in the text:

NIMH (2003)

If the name of the group is short or when its abbreviation would be incomprehensible we should indicate its full name whenever we cite it as a source.

First citation of the source in the text:

University of Pittsburgh (2005) or (University of Pittsburgh, 2005)

Second citation of the source in the text:

University of Pittsburgh (2005) or (University of Pittsburgh, 2005)

\section{Authors with the same surname}

If the list of sources includes sources where two or more primary authors have the same surname, our quotation in the text should, throughout the text, include the initials of the first author. Initials help the reader distinguish between the authors with the same surname in the list of sources:

Sources in the list of sources:

Light, I. (2006). Deflecting immigration: Networks, markets, and regulation in Los Angeles. Russell Sage Foundation.

Light, M. A. and Light, I. H. (2008). The geographic expansion of Mexican immigration in the United States and its implications for local law enforcement. In Law Enforcement Executive Forum Journal 8(1), 73-82.

Citation of the source in the text:

Among other things we also researched the study by M. A. Light and Light (2008), and I. Light (2006).

\section{Works by anonymous authors or unidentified authors}

When it is impossible to identify the author of a certain text we should cite the first few words of the source from the list of sources (most often the title) and the year of publication. Citation 
should include a part of the title, chapter, or title of the website placed in brackets (» «), whilst the title of the book, brochure or report should be written in italic fonts:

... made a splendid achievement (»Study Finds«, 2007)

The book College Bound Seniors (2008) talks about ...

EXCEPTION: When the author of a certain text defines himself as »anonymous « we should indicate the citation in the text as:

(Anonymous, 2013)

\section{Several authors with the same thought}

If the same thought or idea was presented by several authors and if we would like to cite all of them, their surnames should be separated with the semicolon $(i)$ and arrange their order alphabetically according to the surname of the first author:

(Kosslyn, 1996, p. 23; Koening, 1999, p. 43; Walker and Saleh, 2000, p. 5)

If the same author or group of authors published several publications in the same year, the year of such publications should be followed by letters a, b, c, etc., and the publication should be cited in such manner. The same applies for the list of sources at the end of the text:

Some studies (Derryberry and Reed, 2005a, 2005b) showed ...

\section{Indirect citation}

Whenever this is possible we should avoid such type of citation and try to acquire the primary reference, i.e. original article by the indicated author. If there is no other way, when the original work is not printed any more or is unavailable or written in a language we do not understand, we should indirectly cite such work in our text in the following manner:

Tavčar (in Ule and Kline, 1996, p. 121) believes, or

Tavčar (as cited in Ule and Kline, 1996, p. 121)

In English this would be written as:

Tavčar (as cited in Ule and Kline, 1996)

\section{Citation of an exact part of the source}

If we would like to cite an exact part of the text from a certain source we should indicate the page, chapter, table, graph, equation in the text being quoted. Here, we should take into consideration that literal quotations should always include the number of the page. When we indicate the number of the page we should use the abbreviation »p.«. When we indicate the chapter we should write the entire word - »chapter«:

(Centers for Disease Control and Prevention, 2005, p. 10)

(Shimamura, 1989, chapter 3)

\section{$\underline{\text { Personal communication }}$}

Personal communication includes letters, notes, e-mail, personal interviews, telephone calls, etc. Sources of personal communication should be cited by using the initials and the surname of the author that we communicated with, and as accurate date as possible: 
T. K. Lutes (personal communication, April 18, 2001) or (T. K. Lutes, personal communication, April 2001)

Note: Personal communication (interviews, telephone call) should be written literary with questions and answers and enclosed to our work as an Annex.

\section{Non-print source}

A source which is still being printed should be cited in the same manner as other works, except that we write »in print« instead of the year of publication. Example:

Walker (in print) determined ...

The same manner should be used to include the work in the list of sources at the end of the article, i.e. the mentioned phrase should be used instead of the year of publication.

\section{Serial citation of the same source}

When the text includes serial citation of the same source and when no other source was cited in between, the first citation of the source may be followed by the following type of citation: (ibid.) when citing a part of the text on the same page, or: (ibid.; p. 30) when citing a part of the same text on another page.

All sources cited in the text (except for personal communication) should be included in the list of sources and vice versa - all works in the list of sources should be cited somewhere in the text.

\subsection{LIST OF SOURCES}

List of sources at the end of the text includes information about the used sources and information about the acquisition of sources. The alphabetically arranged list of sources only includes sources that were cited in the text without the sources of personal communication.

\subsubsection{PREPARATION OF THE LIST OF SOURCES}

The basic purpose of the list of sources is to enable the reader to acquire and use the sources which is why it should be complete and properly prepared. Each entry usually includes the following elements: author, year of publication, title and data about the edition - all information required for identification and library searching for sources. The best way to ensure accurate and complete information is to review each source and to compare it with the original publication. Special attention should be paid to the proper spelling of names and words in a foreign language, including the accent marks and other punctuation marks and the completeness of the titles of magazines, year of publication, edition number, pagination and electronic acquisition of data. The authors are responsible for all information indicated in the list of sources (APA, 2010, p. 180). 


\section{Alphabetical spelling of sources}

Sources should be arranged in alphabetical order of surnames of first authors followed by the initial of the author's name.

\section{Different works by the same author}

When arranging different works by the same author we should take into consideration the following rules.

- Works should be arranged in a chronological order from the oldest to the newest:

- Upenieks, V. (2003)

- Upenieks, V. (2005)

- If two works by the same author were published in the same year, the year of publication of the first work should be followed by the letter a (example: 2013a), whilst the year of publication of the second work should be followed by the letter $b$ (example: 2013b):

- Baheti, J. R. (2001a). Control ...

- Baheti, J. R. (2001b). Roles of ...

- If an individual author appears in the list as an independent author and as the coauthor we should first indicate his independent work followed by the work he prepared as a co-author (even if the work prepared by several authors was chronologically published before):

- Alleyne, R. L. (2001)

- Alleyne, R. L. and Evans, A. J. (1999)

- In case of works by different authors with the same surname we should alphabetically arrange the works in accordance with the initials of the first name:

- Mathur, A. L. and Wallston, J. (1999)

- Mathur, S. E. and Ahlers, R. J. (1998)

\section{Arrangement of works prepared by groups and works without authors}

Authors of certain works can also be groups, agencies, associations, and institutions. It is also possible to find certain works without authors. Such works should also be alphabetically arranged in the list of sources amongst the other authors according to the first word of the name of the group, agency, institution, etc. The list should include official full names of such entities (example: American Psychological Association and not APA).

When an author is indicated as »anonymous «, the work should be indicated with the word Anonymous written first.

In case of works without authors, the name of the author should be replaced with the title of the work. 
Legal documents should be treated as sources without authors. This means that they should be alphabetically arranged according to the first word or abbreviation of the entry of the source.

Sources are not numbered and should not have any line markings placed in front of them. Each source should be arranged as a new paragraph and when an individual source is cited in several lines, the second line should be indented to the right in order to make a hanging indent of the paragraph:

Light, I. (2006). Deflecting immigration: Networks, markets, and regulation in Los Angeles. Russell Sage Foundation.

\section{Special characteristics of foreign surnames}

In case of authors with surnames, such as van der Borg, de Albuquerque and similar surnames you should take into consideration that the predicates »van« and »de« represent integral parts of the surname. An author with the surname van der Borg should therefore be included in the list of literature and sources under the letter $\mathrm{V}$; the same applies for an author with the surname de Albuquerque - he should be included in the list of literature and sources under the letter $D$.

Hint: For easier preparation of the list of sources and its proper formation you can help yourself with the Google scholar internet browser where you can search for literature (academic literature) you would like to cite and click on option »cite« to acquire the list of entries of the selected literature. Select the APA entry. When you copy the entry to your document take special care to keep the italic fonts (keep the form). It is reasonable to check every citation acquired with the help of Google scholar browser because it can happen that citations are not in accordance with the rules by APA. Examples are presented on figure 2 and figure 3.

Figure 2: Citation of sources with the help of Google scholar No. 1

Tourism destination brand identity: The case of Slovenia
M Konecnik, F Go - Journal of Brand Management, 2008 - Springer
Abstract This paper explores the concept of tourism destination brand identity from the
supply-side perspective, in contrast to those studies that have focused on the demand-
driven, tourists' perceived tourism destination brand image. Both researchers and
Navedeno v 219 virih Sorodni članki Vse različice: 7 Navedi Shrani Več

Source: Google, 2017

\footnotetext{
${ }^{4}$ Google scholar is intended to search for articles, dissertations, books, reports and other academic literature from various sources - publishers, open access archives, academic institution websites. The search also takes place according to the cited literature.
} 
Figure 3: Citation of sources with the help of Google scholar No. 2

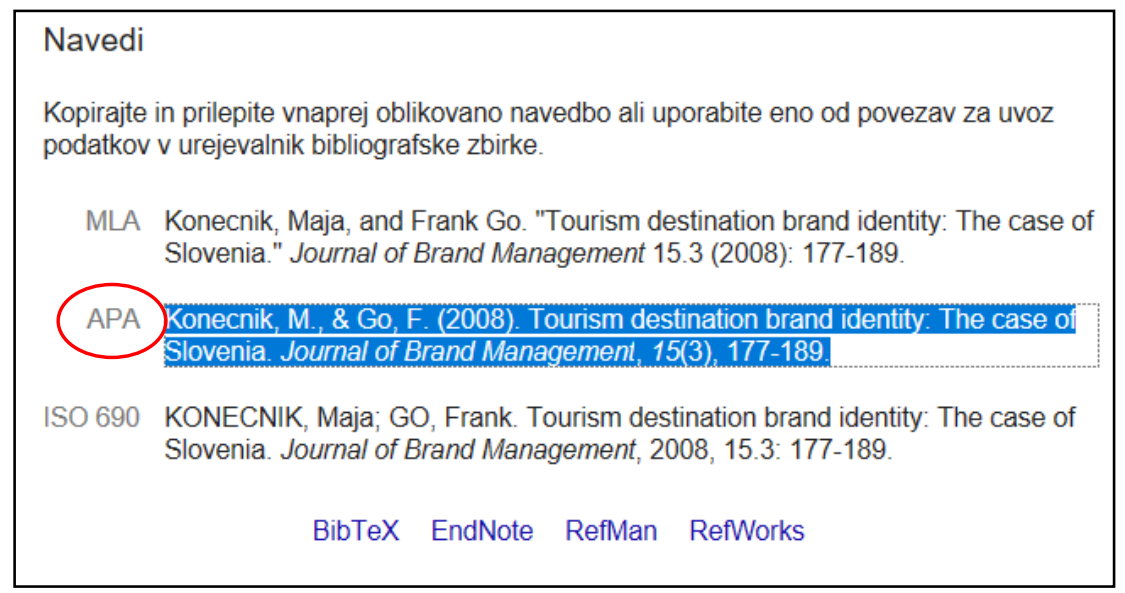

Source: Google, 2017

Apart from this accessory you can also use several other programs that can be used to help yourself when citing sources and establishing the list of literature, such as Mendeley, EndNote, UMNIK, etc.

\subsubsection{RULES FOR CITING SOURCES IN THE LIST OF LITERATURE}

\section{One to seven authors}

In case of a source with one to seven authors we should indicate all authors (surnames and large initials of the name) and place the conjunction word »and « in front of the last author:

Surname, I., Surname, I. and Surname, I. (year of publication). Title. Place: Publisher.

Domen, B., Pucko, D. and Sutherland, R. (1992). Economics and business organization. Ljubljana: Faculty of Economics.

\section{Eight or more authors}

In case of a source with eight or more authors we should indicate the first six authors followed by the ellipsis and the last author.

Gilbert, D. G., McClernon, F. J., Rabinovich, N. E., Sugai, C., Plath, L. C., Asgaard, G., ... Botros, N. (2004). Effects of quitting smoking on EEG activation and attention last for more than 31 days and are more severe with stress, dependence, DRD2 A1 allele, and depressive traits. Nicotine \& Tobacco Research, 6(2), 249-267.

In the text the source should be cited in the following way: (Gilbert et al., 2004, p. 250).

\section{Two authors with the same surname and initials of the name}

When a certain work was prepared by two authors with the same surname and initials of the name we should write the authors full name in square brackets behind the initial of the name: 
Janet, P. [Paul] (1928). L'evolution de la memoire et de la notion du temps (Vol. 1). Paris: A. Chahine.

Janet, P. [Piere] (1906). On the pathogenesis of some impulsions. The Journal of Abnormal Psychology, 1(1), 1.

In the text the source should be cited in the following way:

(Paul Janet, 1928, p. 10)

(Paul Piere, 1906, p. 12)

\section{Group of authors}

Authors of certain works can also be groups, agencies, associations, and institutions. It is also possible to find certain works without authors. In case of a group of authors we should use the official full names of such entities (e.g. American Psychological Association and not APA).

American Psychological Association. (1994). Publication manual of the American psychological association. Washington: American Psychological Association.

In the text the source should be cited in the following way:

- First citation of the source: (American Psychological Association [APA], 1994, p. 113)

- All other citations: (APA, 1994, p. 190)

\section{Sources with editors}

When a certain source has an editor or editors we should indicate them behind the title of the work where the editor should be preceded by the word In. Editors should be indicated by first indicating the initial of the name, surname, followed by (Ed.).

Plath, S. (2000). The unabridged journals. In KV. Kukil (Ed.). New York, NY: Anchor.

Works where only the editor is known (without authors):

Gibbs, J. T. (Ed.). (1991). Children of color: psychological interventions with minority youth. San Francisco: Jossey-Bass.

\section{Source being printed}

When citing a source that is still being printed and has not yet been published we should use the phrase »in print « instead of the year of publication:

Briscoe, R. (in print). Egocentric spatial representation in action and perception.

\section{$\underline{\text { Unknown year of publication }}$}

In case of the unknown year of publication we should use the abbreviation n.d. instead of the year of publication (meaning: no date). In the text we should use the abbreviation n.d. 


\section{Use of italic fonts}

In monograph works (books, diploma theses, master's theses, doctoral dissertations, research reports, articles from conference journals, etc.) italic fonts are used to indicate the title of these works.

In articles (magazines, newspapers, periodicals, etc.) italic fonts are used to indicate the name of the magazine and the year of publication/volume.

\section{Online source access date}

Besides the link to the website all sources found online should indicate the access date that should follow URL-address of the material/source. Citation of such sources is shown with the examples in the following sections.

\subsubsection{EXAMPLES OF CITATIONS OF SOURCES IN THE LIST OF SOURCES ACCORDING TO THE TYPE OF THE SOURCE}

In the following section we will present examples of citations in the list of sources according to a certain type of the source.

\section{ARTICLES IN MAGAZINES, NEWSPAPERS, PERIODICALS}

Surname, Initials of the name. (year of publication). Title. Name of the magazine, volume(number), first page of the article-last page of the article.

Prašnikar, J., Cirman, A. and Domadenik, P. (2001). Investment activities of Slovenian companies in the countries of former Yugoslavia. Economic and business review, 3(2), 137-154.

\section{Articles in magazines accessed online}

Prašnikar, J., Cirman, A. and Domadenik, P. (2001). Investment activities of Slovenian companies in the countries of former Yugoslavia. Economic and business review, 3(2), 137-154. Source: http://www.xxxyyy, access date.

\section{Articles in newspapers and periodicals}

Weiss, M., Šimac, J. and Elikan, J. (May 17, 2012). Prihodnost za gradbeništvo zlasti na tujih trgih. Finance, No. 61, p. 6-7.

\section{Articles in newspapers and online periodicals}

Weiss, M., Šimac, J. and Elikan, J. (May 17, 2012). Prihodnost za gradbeništvo zlasti na tujih trgih. Finance. Available from: http://www.finance.si/347316/Prihodnost-zagradbeni\%C5\%A1tvo-zlasti-na-tujih-trgih, May 4, 2017.

\section{Articles in newspapers and periodicals - without authors}

Six Sites Meet for Comprehensive Anti-Gang initiative conference. (November/December 2006). OJJDP News @ a Glance. Available from: https://www.ncjrs.gov/html/ojjdp/news_at_glance/216684/topstory.html, May 4, 2017. 


\section{BOOKS, CHAPTERS IN BOOKS}

When citing books we should use the following form:

Surname, Initials of the name. (year of publication). Title. Place: Publisher.

Surname, Initials of the name. (year of publication). Title. Available from: http://www.xxyy..., access date.

Surname of the editor, Initials of the name. (Ed.) (year of publication). Title. Place: Publisher.

\section{Printed books}

Potočnik Topler, J. (2017). On tourism discourse and other issues in tourism: scientific monograph. Harlow [etc.]: Pearson.

\section{Electronic version of the published book}

Speed, H. (2004). The practice and science of drawing. Available from: http://www.gutenberg.org/etext/14264, May 5, 2017.

\section{Books with unknown author}

Publication Manual of the American Psychological Association (5th Ed.). (2003). Washington, DC: American Psychological Association.

\section{Chapter in the book}

Surname, Initials of the name. (year of publication). Title of the chapter. In Initials of the name of the editor. Surname of the editor (Ed.), Title of the book (p. first page of the chapterlast page of the chapter). Place: Publisher.

Zgaga, P. (2001). Znanje je moč, je (lahko) tudi stvar demokracije? In K. Majerhold (Ed.), Ali se univerza vrti v krogu svoje moči? (p. 9-26). Ljubljana: Študentska organizacija Univerze v Ljubljani.

\section{RESEARCH REPORT}

\section{Printed research report}

Surname, Initials of the name. (year of publication). Title (Research report). Place: Publisher.

Devjak, T., Cencič, M. and Polak, A. (2005). Model izpopolnjevanja oziroma stalnega strokovnega izpopolnjevanja kot oblike vseživljenjskega učenja strokovnih delavcev $v$ vzgoji in izobraževanju (Research report). Ljubljana: Pedagoška fakulteta.

\section{Electronic research report}

Devjak, T., Cencič, M. and Polak, A. (2005). Model izpopolnjevanja oziroma stalnega strokovnega izpopolnjevanja kot oblike vseživljenjskega učenja strokovnih delavcev $v$ vzgoji in izobraževanju (Research report). Available from: http://www2.arnes.si/ icerar/Devjak,Polak_Nadaljnje\%20izobrazevanje.pdf., May 5, 2017. 


\section{Article in the journal, without the editor}

Surname, Initials of the name. (Month, year of publication). Title of the article. In Title of the journal. (p. first page of the article-last page of the article). Place: Publisher.

Katz, I., Gabayan, K. and Aghajan, H. (August, 2007). A multi-touch surface using multiple cameras. In International Conference on Advanced Concepts for Intelligent Vision Systems (p. 97-108). Berlin: Springer Berlin Heidelberg.

\section{Article in a journal, with the editor or several editors}

Armstrong, D. B., Fogarty, G. J. and Dingsdag, D. (2007). Scales measuring characteristics of small business information systems. In W-G. Tan (Ed.), Proceedings of Research, Relevance and Rigour: Coming of age: 18th Australasian Conference on Information Systems (p. 163-171). Toowoomba, Australia: University of Southern Queensland.

\section{Electronic articles from conferences, congresses and symposiums}

Taylor, J. A. (November 2006). Assessment: a tool for development and engagement in the first year of university study. Article presented in the conference Engaging Students: 9th Pacific Rim in Higher Education (FYHE) Conference, Griffith, Australia. Available from: http://www.fyhe.com.au/past_papers/2006/Papers/Taylor.pdf, May 6, 2017.

\section{DIPLOMA THESIS, MASTER'S THESIS OR DOCTORAL DISSERTATIONS}

\section{Printed diploma thesis, master's thesis or doctoral dissertation}

Surname, Initials of the name. (year of publication). Title. (Diploma thesis). Name of the institution, Place.

Surname, Initials of the name. (year of publication). Title. (Master's thesis). Name of the institution, Place.

Surname, Initials of the name. (year of publication). Tit/e. (Doctoral dissertation). Name of the institution, Place.

\section{Electronic diploma thesis, master's thesis or doctoral dissertation}

Surname, Initials of the name. (year of publication). Title. (Diploma thesis, Name of the institution). Available from: http://www.xxyy, access date.

Surname, Initials of the name. (year of publication). Title. (Master's thesis, Name of the institution). Available from: http://www.xxyy, access date.

Surname, Initials of the name. (year of publication). Title. (Doctoral dissertation, Name of the institution). Available from: from http://www.xxyy, access date.

\section{Unpublished work or informally published work}

Unpublished works are works that are still in the phase of preparation but approved for publication, or works that were already finished but have not yet been published. 
Surname, Initials of the name. (year of publication). Title. Unpublished work.

Surname, Initials of the name. (year of publication). Title. Work submitted for publication.

Surname, Initials of the name. (year of publication). Title. Work in the phase of preparation.

Example:

Kremžar, B. (1985). Motorika predšolskega otroka: študijsko gradivo. Unpublished work.

\section{ARTICLES FROM WEBSITES}

Sources from websites are cited in the same manner as books, articles, followed by the online address where the source was acquired and the access date.

\section{$\underline{\text { Popular websites }}$}

Author. (date of the last update or copyright date; if there is no date this should be indicated with n.d.). Name of the document. Source: URL of the document, access date.

Beard, M. (2006). The fall of the Roman Republic. Available from: http://www.bbc.co.uk/history/ancient/romans/fallofromanrepublic_article_01.shtml, May 4, 2017.

\section{Websites of universities, faculties}

Author. (date of the last update or copyright date; if there is no date this should be indicated with n.d.). Name of the document. Source: name of the university's website: URL of the document, access date.

Johnson, K. A. and Becker, J. A. (2007). The whole brain atlas. Available from: Harvard University Medical School website: http://www.med.harvard.edu/AANLIB/, May 4, 2017.

\section{Websites without dates}

Author. (n.d.). Name of the document. Source: URL of the document, access date.

Royal Institute of British Architects. (n.d.). Shaping the future: Careers in architecture. Available from: http://ww.careersinarchitecture.net/, May 5, 2017.

$\underline{B \log S}$

Hagon, P. (September 27, 2009). Immediate sharing [Web log post]. Available from: http://www.paulhagon.com/ blog/2009/09/27/immediate-sharing/, May 5, 2017.

\section{Website of a company or organization}

Terme Čatež. (n.d.). Source: http://www.terme-catez.si/, May 5, 2017.

\section{Articles from websites without authors}

»Six sites meet for comprehensive anti-gang initiative conference«. (November/December, 2006). OJJDP News @a Glance. Available from:

http://www.ncjrs.gov/html/ojjdp/news_at_glance/216684/topstory.html, May 5, 2017. 
Note: When online articles have no authors you should indicate the title of the article in quotation marks instead of the author in the list of literature and sources. In the text this should be indicated by using the abbreviated title (example above: (»Six Sites Meet ", 2006)); when the title is short it should be fully indicated.

\section{OTHER SOURCES}

\section{Internal material of a company, organization}

Merkur, d. d. (2008). Sistemizacija delovnih mest v podjetju Merkur, d. d.. Internal material. Kranj: Merkur, d. d.

\section{Television or radio shows}

Šterbucl, S. (editor). (2008). Dnevnik [Television show]. Ljubljana: RTV Slovenija.

\section{Video material}

Cage, K. (Writer). (2008). Time management for university students [DVD]. New Zealand: Massey University.

\section{Brochures}

Surname, Initials of the name. (year of publication). Title of the brochure. [Brochure]. Place: Publisher.

\section{Legislative sources}

Zakon o varnosti cestnega prometa. Official Gazette of the Republic of Slovenia, No. 56/2008UPB5, 57/2008-ZLDUVCP, 73/2008 Decision of the Constitutional Court: U-I-295/05-38, 58/2009, 36/2010, 106/2010-ZMV, 109/2010-ZCes-1, 109/2010-ZPrCP, 109/2010-ZVoz, 7/2011 Decision of the Constitutional Court: U-I-144/09-13, 39/2011-ZJZ-E, 47/2011 Odl.US: U-I-119/10-6.

\section{Literature:}

American Psychological Association. (2010). APA manual (publication manual of the American Psychological Association). Washington, DC: American Psychological Association.

Google scholar. (2017). Search criterion: Tourism destination brand tha case of Slovenia. Available from: https://scholar.google.si/scholar?q=tourism+destination+brand+tha+cese+of+slove nia\&btnG=\&hl=sl\&as_sdt=0\%2C5, May 18, 2017.

Lipson, C. (2011). Cite right: a quick guide to citation styles- MLA, APA, Chicago, the sciences, professions, and more. Chicago: University of Chicago Press. 


\title{
CHAPTER 8
}

\section{FORMATTING OF THE TEXT}

\author{
Author: Nejc Pozvek
}

DOI: https://doi.org/10.18690/978-961-286-076-9.8

In the chapter about the formatting of the text we will deal with two different aspects. In the beginning we will present how to break down the text into separate units (frequently used terms are also structuring of the text or cut down of the text) which is actually one of the first, elementary phases in the preparation of each text and logically follows the research process (see chapter 3). In the second part of this chapter we will deal with technical editing of the text which predominantly includes skills of using or mastering various text formatting tools in our case the formatting will be presented on the example of the use of the MS Office Word program which is most frequently used. Technical skills can be acquired through own research, at various classes or with the help of manuals found online and in libraries. The final objective of technical formatting is uniform appearance which is precisely prescribed with certain detailed instructions.

\subsection{Structuring of the text}

When establishing the basic structure of the text we have to break down the text into individual chapters, subchapters, etc. The structuring process begins with the initial design of the thesis - before the idea is put on paper. In case of final papers, the preparation of disposition represents the part of the process of preparation where we determine/establish the structure of the text. Also in the case of all other works or thesis it is reasonable to determine the structure before writing (during the design or development of the idea), because this can considerably facilitate our future work. Structure of seminar papers is most often predefined on the basis of the content to be presented in the paper.

Professional and scientific texts (as well as literary and other texts) follow the classical design - their structure includes three parts: introduction, body and conclusion. These parts are used to present, analyse and solve a certain (research) problem. Each of these three fundamental content components can be arbitrary broken down into chapters and sub-chapters that logically lead us from the starting to the end point of the text.

INTRODUCTION has to include:

- definition and description of the problem (we should try to establish the definition in a clear and concise manner, the most appropriately in a single sentence, whilst the description of the problem usually requires more space);

- purpose and objectives of the research,

- hypotheses or research questions;

- presumptions and limitations of the research, and

- research methods. 
It is very advisable that the introduction also includes indication of the author's personal motives for the selection of the topic where we explain why we decided to select a certain topic, how did we get to this topic, how the research thought was developed, etc.

The BODY which represents the central part of the text should include a more detailed description/presentation of the topic. We should draw on the (relevant!) domestic and foreign literature which we use to develop and explain the selected topic. The body is usually divided into the:

- theoretical part (entitled in accordance with the content of the thesis and reasonably broken down into chapters; the key elements of this part include previous findings about this topic, i.e. presentation of the already existing literature);

- empirical part (discussion of the methodology, critical analysis, confirmation or rejection of the established hypotheses or answers to the research questions) and

- research results (suggested solutions of the problem).

In the CONCLUSION of the text we should not forget about the:

- final thoughts,

- summary of the research findings,

- analysis of the achieved objectives (in comparison with the set objectives),

- analysis and estimate of the work from the perspective of its purpose (was the purpose achieved or not), and

- definition of suggestions for further research.

\subsection{Technical editing of the text}

As we already presented before, technical editing requires certain skills or knowledge related especially to the knowledge of editing software. The most recognized software amongst the word editing program is most certainly the MS Word program from the Microsoft Office collection of software. Our examples of editing in the following sections are based on this very program. The objective of technical editing is the aesthetic and mainly (in our case) uniform appearance of all works. With its instructions and directions which are presented in the following sections, the Faculty of Tourism sets its own standards. They mainly follow the generally established, uniform rules, whilst specific details are very rare. To a certain extent, our design of the instructions draws on the already established rules of other faculties of the University of Maribor ${ }^{5}$.

\footnotetext{
${ }^{5}$ Design of our instructions about technical formatting or editing of texts primarily draws on the document entitled Navodila za izdelavo pisnih del na Ekonomsko-poslovni fakulteti Univerze v Mariboru (Instructions fort he preparation of written work at the Faculty of Economics and Business of the University of Maribor) (authors: Simona Sternad, Darja Boršić and Polona Tominc) that was published in September 2013. In these instructions the students can also find numerous useful hints that make the work with MS Word easier and we certanly encourage the students to use them. Instructions are also available online.
} 
As a key accessory that facilitates technical formatting of the text the students should use the Template for the preparation of final papers at the Faculty of Tourism of the University of Maribor $^{6}$ and the Template for the preparation of seminar papers at the Faculty of Tourism of the University of Maribor that were edited and updated during the preparation of these instructions. These templates provide practical examples that provide visual information and a chance to check the written instructions which allows much better understanding. Especially their use guarantees appropriate formatting, uniform appearance of works and less complications during the technical review of works.

\subsubsection{General rules for formatting/editing texts}

Amongst the general rules we will discuss the basic rules regarding the setup of the page and margins, fonts and paragraphs, formatting of graphical elements (figures and tables) in the text, formatting of equations, pagination and some other details.

\section{- Setup of the page and margins}

At the very beginning of formatting texts we should setup the page (these settings are most often already programmed (default)) where we should take into consideration the size of the paper (A4) and appropriate margins ( $2.5 \mathrm{~cm}$ on both sides). In case of a hard copy of the written work we should also set the binding margin $(1 \mathrm{~cm})$. In this case we should also pay attention to printing: Mirror margins should be set for both-side printing.

Written works should also take into consideration environmental awareness and should therefore be printed on both sides. Exception applies to first pages of final papers (until the introductory (first) chapter) which should be printed on one side only. When preparing written non-final papers we should check the potential additional instructions by individual mentors, lecturers or assistants: Most often it is sufficient to submit electronic versions of the paper. In other cases we should use both-side printing.

Orientation of pages should be portrait. As an exception (in cases of large tables or graphs), the orientation of a certain page may be landscape. This is done by »isolating « the landscape page any by inserting page breaks (new page).

\section{- Fonts and paragraphs}

Throughout the entire paper we should only use one font type. The selection of font types includes: Arial, Times New Roman, Tahoma and Calibri fonts. Font colour should always be black.

The body should be written with font size set to $\mathbf{1 2} \mathbf{~ p t}$. and aligned on both sides (justify). Bold and italic fonts should only be used as exceptions for important emphasis; underlining should be avoided. (in these handbook, bold and underlined texts are included as formatting

\footnotetext{
${ }^{6}$ Template for the preparation of final works at the Faculty of Tourism of the University of Maribor is available on the website of the faculty. It can be accessed directly via the attached link. Apart from the mentioned template, the same tab of the website also includes the Template for the preparation of seminar papers at the Faculty of Tourism of the University of Maribor and all other information regarding the preparation of (final) papers.
} 
elements due to the nature/type of the work. Such type of writing is generally not used in written works.)

Even before starting writing it is reasonable to set the style of the body of the text (some information about the setting of the style can be found in the following sections) which will be used throughout the entire paper. In the Paragraph tab you should set the spacing before to 0 pt., and the spacing after to 12 pt. (1 line). Paragraphs will therefore be automatically separated with a single line (12 pt.). There should be no indent before the first word of the paragraph. There should be single spacing between the lines.

\section{- Chapter titles}

Chapters of the paper should be hierarchically structured. An individual chapter may include several sub-chapters, but in any case at least two. Chapters are formed with several paragraphs. If they are extremely long, we should try to reasonably divide them into smaller units. Titles of different level chapters should not follow one another. There should always be some text separating them.

$\mathbf{1}^{\text {st }}$ level chapter titles should be aligned left and written with bold capital letters and the font size set to $16 \mathrm{pt}$. The main titles should always start on a new page - spacing before the title should therefore be set to 0 pt., whilst spacing after the title should equal two empty lines (24 pt.).

$\mathbf{2}^{\text {nd }}$ level subtitles should be aligned left and written with bold lowercase letters and the font size set to $14 \mathrm{pt}$. (except foot the mandatory large initials). Spacing before the subtitle ( ${ }^{\text {nd }}$ level) should be set to 18 pt., whilst spacing after the subtitle should be set to $12 \mathrm{pt}$. (in structuring, as already indicated above, we should avoid cases where the main title would be directly followed by a subtitle - the same applies to lower levels. Otherwise, criteria regarding chapter formation will also be broken.)

$3^{\text {rd }}$ level subtitles should be written with bold lowercase letters and the font size set to 12 pt. (taking into account large initials). Spacing before and after the subchapter ( $3^{\text {rd }}$ level) should be set to $12 \mathrm{pt}$.

Chapters of all levels should be numbered with Arabic numbers. In case of several levels of subchapters, numbers of chapters should be separated with a full stop (no space), whilst there should be no full stop after the last number - in this place the text of the title should start. Numbering of chapters is simple. You should use different styles that also allow simple insertion of the Table of Contents. If preset styles (customizable) were used, it is the simplest way to use the appropriate multi-level list to number chapters. Such list is already prepared in MS Word.

\section{- $\quad$ Formatting of graphical elements}

Figures (graphs, diagrams, photographs, etc.) and tables are used to provide the reader with a more transparent and clearer presentation of data. These elements should be reasonably included in the text; we should try to mention them before the presentation. They also require referencing (reference element should be precisely defined, e.g. Figure 1 shows ...) and explanation. Caption of the graphical element includes the marking of the element 
(Figure or Table), serial number (including colon; numbering continues throughout the entire written work) and the title of the inserted figure or table (large initial).

For easier subsequent editing of tables of content it is reasonable to arrange all captions above graphical elements in the References tab where the appropriate caption is inserted (Figure or Table). Captions should be centred (as well as graphical elements) and their font size set to 12 pt. Spacing before the caption should be set to 0 pt., whilst the spacing between the inscription and the graphical element should be set to 6 pt. Below the graphical element we should cite the source (sometimes also notes) which should be centred and written in italic with the font size set to $\mathbf{1 0} \mathbf{p t}$. Spacing from the graphical element should be set to $6 \mathrm{pt}$., whilst spacing below the source (note) should be set to $12 \mathrm{pt}$. If we have to indicate a note as well as the source under the graphical element, the spacing between them should be set to 6 pt.

If the graphical element is our own independent work (exceptions include photographs where the author should be indicated) it is not necessary to cite the source. The caption of the source depends on the method of summarizing or data processing. If a graphical element is the same as in the original work, this should be indicated in the following way: »Source: citation of the source, year of publication, page«. If we used certain data in the preparation of the graphical element, this should be indicated in the following way: "Source of data: citation of the source, year of publication«. If a certain graphical element was adapted, this should be indicated in the following way: »Adapted from: citation of the source, year of publication, page«.

\section{- Special table formatting characteristics}

In the same document, tables should have uniform appearance. In principle, tables should spread from the left to the right margin, except where this is unreasonable due to the small volume of information. In such cases, tables should be centred. Tables should always include the heading ( $1^{\text {st }}$ line) and in most cases also the top ( $1^{\text {st }}$ column) where it is appropriate to write the text in bold and coloured letters (e.g. 10\% grey shading). Font size in the table should be set to $12 \mathrm{pt}$. (in case of a large volume of text it can exceptionally be smaller, e.g. $11 \mathrm{pt}$.), there should be single line spacing between the lines, whilst there should be no spacing before and after paragraph. All data should be aligned reasonably (and uniform) according to the content. The external border of the table should be double, whilst the internal borders should be single.

\section{- Formatting of equations}

Equations should always be written in italic (font size 12 pt.) and centred. On the right side of each equation (in the same line of the equation) we should mark the equation with an Arabic number in brackets. For easier formatting of the equation in the mentioned manner you may help yourself by inserting the table (one row, two columns) with invisible edges. There should be an empty line before and after the equation (12 pt.).

\section{- Footnotes}

Footnotes (notes under the line) are used to explain the text in more details or to direct the reader to other sources. As an exception, footnotes may be used to cite a source (e.g. as cited in: Surname of the author, year of publication) from which we cite an entire chapter. This type 
of citation is not appropriate (not allowed) for final works. Footnotes should be written in form of sentences (ended with the full stop) with font size set to 10 pt., centred, and with spacing before and after the chapter set to 0 pt. Footnotes are inserted with the help of the References tab.

\section{- Pagination}

Pages should be paginated at the bottom of the page - with Arabic numbers aligned at the centre of the page. The first numbered page should be the Introduction, whilst the last numbered page should be Literature and sources (numbering of annexes is described in the following sections). Title pages (and other pages before the Introduction) should not be numbered. It applies for the final papers that we may, if we want to, use Roman numbers (I, II, III, etc.) to number the pages from the Acknowledgment to the end of the Tables of Content or the List of Abbreviations. Annexes enclosed at the end of the paper should also be numbered with Arabic numbers where we should start over with number 1 .

In the above described numbering method we should, at appropriate places, mandatory insert page breaks and, during the formatting of the number of the page, select which number we would like to start with and where. We can also help ourselves with various MS Word options located in the Header and Footer tab.

\section{- Lists}

When listing, we should above all select/distinguish between the numerical and line lists; the first type is used when listing order is important, whilst the other type is used when listing order is not important. Numerical or character markings should be used in a uniform manner throughout the entire paper, which means that we should constantly use one type/form of numbers/characters. It is reasonable to properly indent the line character and the beginning of the text according to the left edge of the page (this should be performed in a uniform manner throughout the entire paper). In case of multi-layer lists we should reasonably indent every next level for $1 \mathrm{~cm}$ towards the centre of the page (this does not apply for chapter titles).

There should be no spacing between the beginning of the list and the last line of the previous text (to which the list is connected), whilst there should be an empty line separating the end of the list from the following text. When listing, we should not ignore punctuation marks: In case of shorter lists we should start with the small initial, we may use a comma or semicolon, whilst listing should end with a full stop (as an exception we can avoid using punctuation marks); longer texts (sentences) should be listed in a form of sentences (large initial + full stop).

\section{- Styles}

In the above paragraphs we often referred to the so-called styles which can be of great help (and extremely useful) in technical editing of the text. Before the actual editing of the paper it is reasonable to set and adjust the styles for use because this can greatly facilitate and accelerate the work. Most of the styles are preset (default), however all of them do not comply with this handbook for written works; settings of such styles can be changed and kept for further use. Styles are used to format the entire text: the main text as well as titles, captions, lists, etc. Titles that we do not want to include in the Table of Contents (Summary, Tables, etc.) 
can also be formatted with styles which is not specifically mentioned in this handbook. In all cases, styles can be used to adjust the settings in accordance with the handbook (spacing before and after, alignment, potential indent of the text, etc.).

- $\underline{\text { Tables }}$

Table of Content is an arranged presentation of the structure of our work which includes the titles of all chapters and sub-chapters and also presents the break-down of the content of the written work. It is reasonable to format it after the conclusion of writing. It is usually comprised of three levels, and in exceptional cases even more (longer works). Insertion of the Table in MS Word is simple if styles were used in a consistent manner. The first chapter in the Table of Content is the Introduction; all elements of the work before the Introduction should be excluded from the Table of Contents.

Technical details of formatting the Table of Contents: The title Table of Contents (font size set to 16 pt., capital letters) should be followed by an empty line (12 pt.) where the presentation of the entire content should be, at the first level, written in bold capital letters with font size set to 12 pt., at the second level with classic settings, whilst the font size at the third level may be reduced to $11 \mathrm{pt}$. Text should be connected with the number of the page (leading line) with dots.

All graphical elements (photographs, graphical presentations, illustrations, etc.), except for tables, should be marked with the caption Figure. Table of figures should be placed on the page following the Table of Content. The title Table of Figures (font size set to 16 pt.) should be followed by an empty line (12 pt.) and Figures in the order of their appearance throughout the written work. Table of Figures should use classic font settings (12 pt., lowercase letters). The text should be connected with the number of the page (leading line) with dots.

Table of Tables may be separated from the table of Figures with two empty lines (24 pt.). It is not necessary to write it in a separate page. The title Table of Tables (font size set to 16 pt.) should be followed by an empty line (12 pt.) and Tables in the order of their appearance throughout the written work. All other formatting is the same as in case of the Table of Figures.

Tables of Figures and Tables are formed automatically with the help of a command in MS Word. This requires that all titles or captions of Figures and Tables are previously appropriately marked in the References tab with the selection of the option Insert caption.

Table of Annexes should be inserted after the title Annexes. It might be the best to mark the titles of annexes with a special style and then use the option Custom Table of Contents to only arrange the Table of Annexes. For easier formatting we recommend you to take a look or use the enclosed template for the preparation of final papers or seminar papers.

\section{- $\quad$ List of Abbreviations}

At the time of the first appearance of an abbreviation in the text, this abbreviation should be followed by the full phrase and explanation in brackets where we should also indicate the future form of writing. From this point, we may always use the abbreviation in the following text. If several $(>10)$ abbreviations appear in the text they should be explained in a special chapter List of Abbreviation following the List of Tables. 
The List of Abbreviations should be formatted in the same manner as Tables of Figures and Tables that were discussed before. In case of a large number of abbreviations it is reasonable to place the Table of Abbreviations on a separate page. Otherwise, the List of Abbreviations may follow the Table of Figures separated by two empty lines ( $24 \mathrm{pt}$.). The font size of the List of Abbreviations should be set to 16 pt. The list should be followed by an empty line and explanation of abbreviations written in font size set to $12 \mathrm{pt}$.

\subsubsection{Special elements when formatting the work}

Final papers (Diploma and Master's thesis) require certain elements, such as hard covers, summary, final words and acknowledgment, which other works do not (these can be explicitly defined with the instructions for the preparation of work). Formatting of individual elements is explicitly defined and presented in the following sections. Here, we would again like to point out the above mentioned templates which can be of great help especially when formatting these elements.

\section{EXTERNAL TITLE PAGE OF THE HARD COPY}

On the hard cover we should indicate data separated by a single line spacing and without any extra spacing before or after the text. Font size should be set to $16 \mathrm{pt}$., except for the title which should be centred on the entire page, written in bold, and the font size set to $20 \mathrm{pt}$. Attention should be paid to capital and lowercase letters. We would like to recommend you the use of the template when formatting the external title page. This template was designed for this purpose and is appended to this handbook. If you do not use the template, the formatting of the external title page should be identical to the formatting from the template.

We also should not ignore the provisions of the third or the fourth paragraph of Article 12 of the Pravilnik o postopku priprave in zagovora zaključnega dela na študijskih programih prve in druge stopnje Fakultete za turizem $\mathrm{UM}^{7}$ (Rules on the procedure of preparation and defence of the final paper for graduate and post-graduate study programmes at the Faculty of Tourism of the University of Maribor) that define the colour of the cover and fonts which is very important for the submission of the final work for printing.

\section{INTERNAL TITLE PAGE}

The internal title page of the hard copy, which is at the same time the first page of the paperback copy, should be formatted in a similar way as the external title page. In the lower part of the page we should indicate the mentor and the co-mentor (font size 14 pt.). Formatting will be the easiest (as well as in case of the external title page) if you follow the template or use it as a reference.

\section{ACKNOWLEDGMENT, SUMMARY AND FINAL WORDS}

The second set of elements which includes the acknowledgment, summary and final words (and also tables of content; until the introduction) should be separated from title pages with

\footnotetext{
7 Rules on the procedure of preparation and defence of the final paper for the first and second cycle of the study programme at the Faculty of Tourism of the University of Maroibor were adopted on March 30, 2017 and is available on the website of the faculty (or via link).
} 
a page break predominantly because of easier formatting. It is unnecessary to number pages with these elements. If we nevertheless decide for pagination we should use Roman numbers (I, II, III, etc.). Before these elements, our final paper should also include (in accordance with the template and instructions) the Statement of authorship and a potential appendix about the temporary unavailability of the work.

The Acknowledgement should be written if we would like to give special thanks to those who helped us in any way during the preparation of the written work. Formatting of the Acknowledgment is presented in the template. (Description of formatting: the title Acknowledgment (12 pt., capital letters, bold) should be followed by an empty line (12 pt.) and the text of the acknowledgment (font size 12 pt.) that should be centred in the same way as all of the following text. There should be single line spacing between the lines. The entire text should be moved to the lower edge of the page.)

\section{- Summary and Final Words}

Summary usually contains from 150 to 200 words. The title of the work (font size 16 pt., capital letters) should be separated from the text with a 12 pt. spacing. The text of the summary should be aligned on both sides and written with the normal font size (12 pt.).

The Summary is followed by an empty line (12 pt.) and Final Words usually written in bold with the normal font size (12 pt.), whilst the phrase should be followed by the colon. Normally, you should select approximately five keywords.

Keywords should be followed by two empty lines (24 pt.) and the entire content also written in the English or German language.

In case of final papers, this page should also include the UDC number (universal decimal classification) written in accordance with the template (24 pt. under keywords in the foreign language).

In case of formatting of all pages until the Tables of Content it is probably the best to use the template. Afterwards, we recommend you to follow the template (showing useful examples), whilst the content should be formatted and prepared by authors themselves.

\subsection{Instead of the conclusion}

The primary concern of the authors of written works should of course remain the content. However, it is very difficult to present even high-quality content to the reader if there is no appropriate presentation (structuring and formatting). The reasonable structure of the content and its arranged appearance are of key importance for its presentation to the listeners and readers. Therefore, we should never underestimate the formatting part (structure and arrangement of the text) because, in most cases, it represents the first contact of the content with the audience - and this contact is extremely important. The written work is of good quality if it covers and considers all aspects of good communication (also presented in this handbook). Its level of quality equals the level of quality of its weakest link. 


\section{Literature:}

Fakulteta za turizem. (2017). Pravilnik o postopku priprave in zagovora zaključnega dela na študijskih programih prve in druge stopnje Fakultete za turizem UM. Brežice: Fakulteta za turizem, Univerza v Mariboru.

Sternad, S., Boršič, D. and Tominc, P. (2013). Navodila za izdelavo pisnih del na Ekonomskoposlovni fakulteti. Maribor: Univerza v Mariboru, Ekonomsko-poslovna fakulteta. 


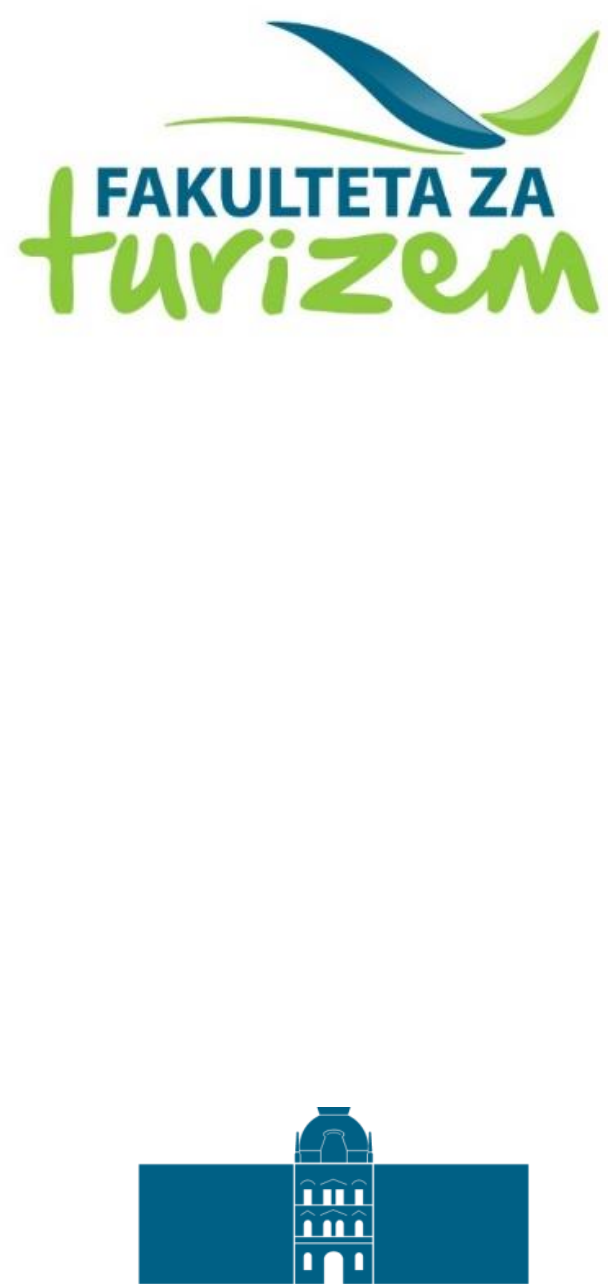

University of Maribor Press 